\title{
Informational Content of Options Trading on Acquirer Announcement Return*
}

\author{
Konan Chan ${ }^{\mathrm{a}, \dagger}, \mathrm{Li} \mathrm{Ge}^{\mathrm{b}, \dot{\dagger}}$, and Tse-Chun Lin ${ }^{\mathrm{b}, \S}$ \\ ${ }^{a}$ National Chengchi University \\ ${ }^{b}$ The University of Hong Kong
}

July, 2013

JEL Classification: G12, G14, G34

Keywords: Merger and Acquisition, Acquirer, Informed Trading, Implied Volatility Spread, Implied Volatility Skew

\footnotetext{
${ }^{*}$ We have benefited from the comments of Gurdip Bakshi, Geert Bekaert, Utpal Bhattacharya, Matthias Buehlmaier, Joost Driessen, Jingzhi Huang, Younghan Kim, Neil Pearson, and seminar participants at European Financial Management Association annual meeting (2012), Asian Finance Association annual meeting (2012), OptionMetrics User Conference (2012), and Financial Management Association annual meeting (2012). Tse-Chun Lin gratefully acknowledges the research support from the Faculty of Business and Economics at the University of Hong Kong and the Research Grants Council of the Hong Kong SAR government. All errors remain our responsibility.

${ }^{\dagger}$ Tel.: +886-2-2939-3091 ext 81239; fax: +886-2-2939-3394. E-mail address: konan@nccu.edu.tw.

${ }^{\ddagger}$ Tel.: +852-2859-1058; fax: +852-2548-1152. E-mail address: geli1019@hku.hk.

${ }^{\S}$ Tel.: +852-2857-8503; fax: +852-2548-1152. E-mail address: tsechunlin@ hku.hk.
} 


\title{
Informational Content of Options Trading on Acquirer Announcement Return
}

\author{
July, 2013
}

\begin{abstract}
This study examines the informational content of options trading on acquirer announcement returns. We show that implied volatility spread predicts positively on the cumulative abnormal return (CAR), and implied volatility skew predicts negatively on the CAR. The predictability is much stronger around actual merger and acquisition (M\&A) announcement days, compared with pseudo-event days. The prediction is weaker if pre-M\&A stock price has incorporated part of the information, but stronger if acquirer's options trading is more liquid. Finally, we find that higher relative trading volume of options to stock predicts higher absolute CARs. The relation also exists among the target firms.
\end{abstract}

JEL Classification: G12, G14, G34

Keywords: Merger and Acquisition, Acquirer, Informed Trading, Implied Volatility Spread, Implied Volatility Skew 


\section{Introduction}

The theoretical literature in options argues that informed traders prefer to trade options rather than stocks due to lower trading costs (or higher leverage) and more efficient trading (Back, 1993; Cao, 1999; Easley, O’Hara, and Srinivas, 1998). Empirical research supports the notion that options trades convey information about future stock prices. For example, Easley et al. (1998) argue that informed traders may prefer the options market when its implicit leverage is high and its trading is more liquid. Pan and Poteshman (2006) find that stocks with low put-call ratios, based on options trades that open new options positions, outperform stocks with high putcall ratios by more than $1 \%$ in the following week. Recent studies also support the existence of informed trading in the options market (e.g., Cremers and Weinbaum, 2010; Johnson and So, 2012; Lin, Lu, and Driessen, 2013; Roll, Schwartz, and Subrahmanyam, 2010; Xing, Zhang, and Zhao, 2010).

However, another strand of research shows that options trading does not contribute to price discovery for the underlying stock. Chan, Chung, and Fong (2002) find that options trading volume has no incremental predictive ability after controlling for stock trading volume. Instead, new information in the options market comes in the form of quote revisions rather than trades. Recently, Muravyev, Pearson, and Broussard (2013) show that even options price quotes do not contain economically significant information that has not been reflected in the stock price quotes. These results seem to suggest that options trading does not provide information to predict future stock price changes.

Our study sheds light on this debate by focusing on the most important corporate events, mergers and acquisitions (M\&As), and by examining whether informed traders indeed capitalize on their private information about the events by trading options. An advantage of examining 
M\&A events is that they are in most cases not known to the general public except for few informed traders. As a result, the stock price prior to M\&A may not incorporate information regarding the forthcoming M\&A. We hypothesize that options trading contains private information of M\&A transactions and thus can be used to predict M\&A announcement returns of acquirers. Specifically, we argue that when some informed traders possess favorable (unfavorable) information that will be reflected subsequently in the stock market around the M\&A announcement, they will buy more calls (puts) in advance to make profits. ${ }^{5}$

We adopt two informed options trading measures, implied volatility (IV) spread as in Cremers and Weinbaum (2010) and IV skew as in Xing et al. (2010), to test their predictability on acquirer announcement returns. We provide supporting evidence by answering the following three questions: Is the predictability stronger around the event days than on other days? Does the predictability get smaller when the information regarding the M\&A has been reflected in the stock price before the announcement? Is the predictability positively associated with the liquidity of options trading as argued by Easley et al. (1998)?

Empirically, our sample covers M\&A events from the Securities Data Company (SDC) Platinum database for the period of 1996 to 2010. For each acquirer, we obtain the daily options data from OptionMetrics to construct our proxies for informed options trading. The IV spread measures the average difference in implied volatilities between call and put options on the same security with the same strike price and maturity. Intuitively, a larger IV spread means that calls

\footnotetext{
${ }^{5}$ Although the literature finds that the average acquirer announcement return is close to zero, large variation exists among $M \& A$ announcement returns. Informed traders can still make profits by buying calls or puts before events with non-zero returns.
} 
are more expensive than puts, indicating a higher buying pressure on call options. ${ }^{6}$ The IV skew measures the difference in implied volatilities between out-of-the-money (OTM) put and at-themoney (ATM) call. A higher IV skew indicates that investors have a higher demand on OTM puts, suggesting a possible drop in the future stock price. ${ }^{7}$

Using the two informed options trading measures at one day before M\&A announcements, we find that a higher IV spread predicts a higher acquirer cumulative abnormal return $(\mathrm{CAR})$ over the two-day $(0,+1)$ window and that a higher IV skew predicts a lower twoday acquirer CAR. In particular, when we run regressions of CARs on IV spread and IV skew, the coefficient for IV spread (IV skew) is $13.85(-9.51)$ with a $t$-statistic of $4.03(-2.58)$ after controlling for a variety of firm- and deal-specific characteristics. Both results are consistent with our main hypothesis.

We conduct several additional tests to substantiate the main hypothesis. First, we show that IV spread and IV skew have a much stronger predictability on the event dates (i.e., M\&A announcements) compared with nonevent dates in simulations. Second, we find that pre-M\&A stock market response, measured by the three-day CAR immediately before M\&A announcements, affects the predictability of informed options trading measures. Third, we find that the predictive power of informed options trading measures is stronger if the acquirer's options liquidity (measured by the bid-ask spread) is higher.

\footnotetext{
${ }^{6}$ For studies adopting IV spread, see, among others, Bali and Hovakimian (2009), Jin, Livnat, and Zhang (2012), and Lin et al. (2013).

${ }^{7}$ For studies adopting IV skew (or IV smirk), see, among others, Bester, Martinez, and Rosu (2011), Bollen and Whaley (2004), Jin et al. (2012), Lin et al. (2013), and Van Buskirk (2011).
} 
We also adopt options to stock volume ratio $(\mathrm{O} / \mathrm{S})$, based on the unsigned volume of options trading relative to the trading of corresponding stock, as an alternative measure of informed options trading. ${ }^{8}$ Furthermore, our results are robust to several alternative definitions of informed options trading measures, such as deciles of IV spread or IV skew and changes in IV spread or IV skew relative to the previous week or previous month. Excluding events with small deal value or small market capitalization does not alter our findings. Finally, we find consistent evidence of IV spread and IV skew in predicting the announcement CARs of target firms.

Our study contributes to the literature by linking informed options trading to acquirer announcement returns. Existing studies (e.g., Cao, Chen, and Griffin, 2005; Arnold, Erwin, Nail, and Nixon, 2006) mainly focus on target firms and find some evidence of informed options trading before the announcements. To the best of our knowledge, our study is the first to examine the return predictability of informed options trading on acquiring firms. We focus on acquiring firms for several reasons.

First, target firms tend to be private, small, and without listed options. By focusing on acquiring firms, we are able to utilize a comprehensive sample of public and relatively larger firms up to date. Even among those target firms with listed options, the liquidity of options may be too low for informed traders to make a profit. The bid-ask spread can widen dramatically when very few contracts are traded. In contrast, acquiring firms tend to be larger with higher options liquidity and thus are more attractive to the informed traders.

Second, because the distribution of acquirer announcement returns is quite dispersed, with an average value close to zero, a good return prediction is difficult. Informed investors can

\footnotetext{
${ }^{8}$ For more discussion on O/S, see Johnson and So (2012) and Roll et al. (2010).
} 
profit on trading acquirer options only if they possess private information regarding M\&A announcements. The excess demand pressure on calls (puts) due to informed traders capitalizing on their positive (negative) private news on forthcoming M\&A events can push up the IV spread (skew). In other words, the cross-sectional variation of announcement CAR is partially captured by the variation of IV spread and IV skew before the event. Conversely, the target announcement returns tend to be positive given the large premium in a typical takeover. Even when informed traders only know about the announcement dates but not the detailed contents, the high chance of positive announcement returns of target firms can still lead to high options trading. As a result, we argue that the examination of acquirers offers a stronger test on informed trading in the options market as informed traders need to know how stock market may respond to the announcements.

Finally, debate exists on whether acquisitions create value for shareholders of acquiring firms (Fuller et al., 2002; Loughran and Vijh, 1997; Moeller et al., 2005). Prior research shows that takeover announcements can be good or bad news for acquirers depending on firm- and deal-specific characteristics. For example, an acquisition may benefit the acquirer when financed by cash or debt or when the target firm is in the same industry (see, e.g., Graham, Lemmon, and Wolf, 2002; Hazelkorn, Zenner, and Shivdasani, 2004; Mara, McConnell, and Stolin, 2006; Savor and $\mathrm{Lu}, 2009)$. We offer a simple approach to evaluate acquisitions by examining informed trading in the options market and thus shed light on the debate in the M\&A literature.

The remainder of the paper is organized as follows. Section II describes our M\&A sample and the two main options measures we use. Section III presents the main hypothesis and results. Section IV offers additional supporting evidence. We test our main hypothesis on target firms in Section V. Section VI concludes the paper. 


\section{Data}

A. M\&A sample

Our M\&A sample is from Securities Data Company (SDC) platinum database and covers the period of January 1996 to December 2010. Daily options data are from OptionMetrics. We require the acquiring firms be listed in NYSE, AMEX, or NASDAQ with daily stock returns in CRSP and annual accounting information in COMPUSTAT. To examine the predictability of pre-event informed options trading, we keep only firms which have available daily options trading prior to their M\&A announcements. We restrict our sample to transactions classified as "merger" or "acquisition of a majority interest" because they are most relevant to our study and contain relatively more transactions. We exclude cases in which the same acquirer announces a merger with several different target firms on the same day because the acquirer return is affected by several announcements simultaneously. On the several occasions in which the acquirer has multiple stocks listed in the exchange, we keep the one with the highest stock trading volume on the day before the M\&A announcement. Our final sample consists of 7,047 merger cases by 2,439 acquiring firms.

Panel A of Table 1 shows the sample distribution by event years. Several acquirers conduct more than one M\&A in a year. Consistent with the previous literature (e.g., Moeller et al., 2004, 2005), relatively more events occurred in late 1990s. Panel B lists the summary statistics of acquirers' firm characteristics. The CAR is calculated by cumulating the abnormal returns from day $t$ to $t+1$, where day $t$ is the M\&A announcement date, or the first trading day after announcement if the announcement date is a nontrading day. We use CRSP value-weighted 
market return as the benchmark in estimating daily abnormal returns. The mean acquirer CAR is $-0.10 \%$ with a standard deviation of $6.52 \% .^{9}$

[Table 1 about here]

Consistent with prior studies (e.g., Harford, Jenter, and Li, 2011), the mean acquirer CAR is slightly negative and close to zero. If we classify M\&A events by their primary payment method, we find that the mean announcement return for cases with cash payment is much higher than that for events with stock payment. This result is consistent with the previous research (e.g., Loughran and Vijh, 1997; Netter, Stegemoller, and Wintoki, 2011).

In Panel B of Table 1, options bid-ask spread is the pre-M\&A five-day average bid-ask spread across all options traded on the firm's equity. The level of options bid-ask spread of acquirers is lower than that of targets, which is listed in Panel B of Appendix Table 2. In general, acquirers have high liquidity in options than targets do. This result is consistent with our conjecture that options trading on acquirers may contain more information due to higher liquidity. Accordingly, we expect to see a stronger result of our informed options trading proxies on acquirer announcement returns.

Analyst coverage equals the number of IBES analyst recommendations in the month before M\&A. Size is the natural logarithm of market capitalization on the day before M\&A announcement. Age is the number of years that a stock has been covered in CRSP before the M\&A announcement. Idiosyncratic volatility is the standard deviation of the residuals from the

\footnotetext{
${ }^{9}$ In Appendix Figure 1, we plot the daily equal-weighted and value-weighted abnormal stock returns for acquirers from $t-30$ to $t+30$. Our result suggests that acquirer returns are quite volatile even in the normal period.
} 
Fama-French three-factor model with daily returns in the pre-M\&A 12 months. Comparing with the statistics in Panel B of Appendix Table 2, acquirers have higher analyst coverage, larger size, older age, and slightly lower idiosyncratic volatility than targets.

\section{B. IV spread}

To examine the informational content of options trading, we make use of two options measures newly adopted in the recent literature. The first is IV spread, which is regarded as a proxy for price pressure in the options market (Cremers and Weinbaum, 2010). Based on deviations from the put-call parity, IV spread is constructed as the average difference in implied volatilities between call options and put options for the same underlying security with the same strike price and the same maturity. ${ }^{10}$ In particular, we compute IV spread for each firm $i$ on each day $t$ as

${ }^{10}$ One concern for the implied volatility is that the stock price process around M\&A events is best described by a jump process while the implied volatility is computed based on the BlackScholes model. We argue that the implied volatility is a one-on-one monotonic transformation from options price to implied volatility. Therefore, as long as the options price has incorporated the jump effect, the implied volatility would be able to reflect the jump partially. We could use the options price directly to construct the informed options trading measures. However, we have to adjust for the impact of some options characteristics on prices such as moneyness. Using implied volatility is a convenient way to compare options prices across different strike prices. We acknowledge that the calculation of the Black-Scholes implied volatility assumes a constant stock-return volatility. However, the concern can be mitigated by the fact that we do not use the level of implied volatility directly as our IV spread or IV skew is the difference in implied 


$$
I V \operatorname{Spread}_{i, t}=I V_{i, t}^{\text {calls }}-I V_{i, t}^{\text {puts }}=\sum_{j=1}^{N_{i, t}} w_{j, t}^{i}\left(I V_{j, t}^{i, \text { call }}-I V_{j, t}^{i, p u t}\right)
$$

See Appendix for a detailed explanation of the construction procedure.

Table 2, Panel A, summarizes the IV spread by year. In general, IV spread is negative, with a mean of -0.0093 and a standard deviation of 0.0505 . As a signed measure of informed options trading activity, IV spread can predict both positive and negative future abnormal returns. Intuitively, if call options are more expensive than put options, the implied volatilities of calls will be higher than those of puts, leading to a positive IV spread. A larger (especially increasing) IV spread means that investors demand more call options, expecting a positive abnormal return on the underlying stock. ${ }^{11}$ Conversely, a smaller (especially decreasing) IV spread is associated with a negative future abnormal stock return. Therefore, if investors in the options market hold private information on an M\&A event, we expect the pre-event IV spread to be positively associated with the announcement return.

[Table 2 about here]

C. IV skew

volatilities between call options and put options. If the biases for the call implied volatility and put implied volatility due to this jump issue are of similar magnitude, the biases would be largely cancelled out. We thank the referee for pointing out this issue.

${ }^{11}$ Cremers and Weinbaum (2010) argue that short sale constraints cannot explain the positive relation between IV spread and abnormal stock returns. 
The other options measure that we adopt is IV skew, a proxy for negative price pressure in the options market (Xing, Zhang, and Zhao, 2010). We calculate daily IV skew for firm $i$ on day $t$ by the implied volatility difference between the out-of-the-money (OTM) put and the at-the-money (ATM) call as

$$
I V S k e w_{i, t}=I V_{i, t}^{\text {OTMput }}-I V_{i, t}^{\text {ATMcall }}
$$

See Appendix for a detailed explanation of the construction procedure.

Panel B of Table 2 shows that IV skew is generally positive, with a mean of 0.0432 and a standard deviation of 0.0527 . IV skew is also a signed measure on informed options trading. If investors hold negative information, they tend to buy put options, especially the OTM puts, either to hedge against future price drop or to speculate on the potential return by buying put options. If more investors are willing to buy OTM puts, the stock prices and implied volatilities of OTM puts will be pushed up, and IV skew will increase. Therefore, a higher demand for OTM put options indicates that investors hold negative news on the firm and expect a lower stock return in near future. ATM call is used as the benchmark because it is the most liquid option and thus can reflect investors' consensus about the uncertainty of the firm. The rationale of IV skew is consistent with the implied volatility functions measured by delta in Bollen and Whaley (2004). Thus in M\&A events we expect a negative relation between pre-announcement IV skew and the announcement return.

\section{Main hypothesis and results}


This section discusses our main hypothesis that options trading prior to an M\&A event contains information on acquirer announcement returns. As previously discussed, we use two signed measures of informed options trading, IV spread and IV skew, to test whether they can predict acquirer announcement CARs.

\section{A. Acquirer announcement CARs sorted by IV spread and IV skew}

To show the relation between announcement returns and informed options trading measures, we sort the sample into quintiles based on pre-announcement IV spread and IV skew, respectively. We expect that the acquirer announcement return will increase with the value of IV spread and decrease with the value of IV skew.

Table 3 shows the mean and $t$-statistics of acquirer CARs for each quintile of IV spread or IV skew. CARs are cumulated from day $t$ to $t+1$ where day $t$ is the announcement date or the first trading day after the announcement if that day is a nontrading day. We use the day $t-1$ value of IV spread and IV skew because the informational advantage of informed traders should be largest right before corporate events, as argued by Skinner (1997). Consistent with our expectation, mean CAR is generally increasing with IV spread. The difference in CAR between the two extreme quintiles is significant and positive, with a mean of $1.67 \%$ and a $t$-statistic of 4.11. However, CAR is decreasing with IV skew in a monotonic pattern. High-minus-low difference equals $-1.02 \%$ with a $t$-statistic of -1.96 . For robustness, we also show the median CAR for each quintile. The results are very similar to the mean values.

[Table 3 about here] 
From the one-way sort analysis, we obtain preliminary supporting evidence for our main hypothesis. The acquirer announcement return is positively correlated with IV spread and negatively correlated with IV skew. In the next subsection, we present cross-sectional regressions to further support our hypothesis.

B. Higher IV spread or lower IV skew is associated with higher acquirer announcement CAR

We argue that a high IV spread (IV skew) reflects investors' expectation of a future upward (downward) price movement around the announcements. We formalize this expectation by running cross-sectional regressions of acquirer announcement returns on informed options trading measures and control variables. The main regression model is specified as

$$
\begin{aligned}
\text { CAR }_{i,[t, t+1]}= & \beta_{0, i}+\beta_{1, i} \text { IV Spread }_{i, t-1}\left(\text { or IV Skew }_{i, t-1}\right) \\
& +\gamma_{1, i} \text { Pre-month Return }_{i, t-22, t-1]}+\gamma_{2, i} \text { Pre-year Return }_{i, t-252, t-23]} \\
& +\gamma_{3, i} \text { Successful }_{i, t}+\gamma_{4, i} \text { Takeover }_{i, t}+\gamma_{5, i} \text { Hostile }_{i, t}+\gamma_{6, i} \text { Rumor }_{i, t}+\gamma_{7, i} \text { Cash }_{i, t} \\
& +\gamma_{8, i} \text { Size }_{i, t}+\gamma_{9, i} \text { B }_{i, t} \\
& +\gamma_{10, i} \text { Year Fixed Effect }+\gamma_{11, i} \text { Industry Fixed Effect }+\varepsilon_{i}
\end{aligned}
$$

where $C A R_{i,[t, t+1]}$ is the two-day cumulative abnormal return around the M\&A announcement date $t$ for each acquiring firm $i$, expressed in percentage. The independent variables of interest are IV spread and IV skew, respectively, on day $t-1$ for each firm $i$. Due to the correlation between IV spread and IV skew, we include them in separate regressions.

With the pre-month return and the pre-year return, we take into account the price change one year prior to each M\&A event. Specifically, pre-month return is the buy-and-hold return compounded from day $t-22$ to $t-1$, and pre-year return is the buy-and-hold return compounded from day $t-252$ to $t-23$. We also consider event-related characteristics which may affect announcement returns of acquirers. Similar to Cao et al. (2005), we add five event-related 
dummies. Successful equals 1 if the merger or acquisition is successfully completed (i.e., the status is "C" as indicated in SDC), and zero otherwise. ${ }^{12}$ Takeover equals 1 if the event is classified as an "acquisition of a majority interest" instead of a "merger" in SDC, and zero otherwise. Hostile equals 1 if the event's attitude is identified as "hostile" in SDC, and zero otherwise. Rumor equals 1 if "deal began as a rumor" is "yes" in SDC, and zero otherwise. Cash equals 1 if the primary payment is cash, that is, the "\% of cash" in SDC is greater than or equal to 50 , and zero otherwise.

Finally, we control for firm characteristics. Size is the natural logarithm of market capitalization on the event day. Book value is calculated as book value per share multiplied by total shares outstanding, where we use the most recent fiscal year end data prior to each event. $\mathrm{B} / \mathrm{M}$ is the natural logarithm of the ratio of book value to market capitalization. We also include year and industry fixed effects.

Table 4 reports the regression results. In Panel A, the pre-event IV spread has a significantly positive association with acquirer announcement CARs. When IV spread is the only explanatory variable, it has a positive and significant coefficient of 13.00 with a $t$-statistic of 3.75 . In Models 2 to 4, we add controls for previous returns, event-related characteristics, and firm characteristics. The predictability of IV spread on acquirer announcement returns is not affected. In Model 5 we include all control variables as well as year and industry fixed effects and find that the IV spread result still holds, with a coefficient of 13.85 and a $t$-statistic of 4.03 . When the

\footnotetext{
${ }^{12}$ Whether the event is successfully complete is a forward-looking measure. It may not be appropriate to include it when predicting the announcement returns. To address this concern, we exclude the "successful" dummy in main regressions, and the results are similar.
} 
IV spread increases by one standard deviation, the acquirer announcement CAR increases by about $0.70 \%$.

Panel B of Table 4 reports the impact of IV skew on acquirer announcement returns. In Model 1 , the IV skew has a coefficient of -9.53 with a $t$-statistic of -2.59 . Adding all control variables does not affect the negative relation between IV skew and acquirer CAR $\left(\beta_{1}=-9.51, t\right.$ statistic $=-2.58)$. One standard deviation increase of IV skew leads to a decrease of the acquirer announcement CAR by about $0.50 \%$.

[Table 4 about here]

We argue that when some investors hold positive (negative) information of an upcoming M\&A event, they will buy more calls (puts). As a result, call (put) options prices will be pushed up, and IV spread (IV skew) will be higher. Our regression results suggest that a higher IV spread (IV skew) is an indication of positive (negative) information held by options traders. The results show that IV spread (IV skew) is positively (negatively) associated with acquirer announcement return. ${ }^{13}$

${ }^{13}$ The design of our empirical test is similar to that in Cremers and Weinbaum (2010) and Xing, Zhang, and Zhao (2010). They both regress weekly stock returns on IV spread and IV skew to examine whether informed options measures have return predictability. Although the average weekly return is almost zero (about $0.18 \%$ ) for firms with options trading in the market, they both find a strong positive correlation between IV spread and next-week return and a strong negative correlation between IV skew and next-week return. Similarly, we can still examine whether options trading have predictability on M\&A acquirer announcement returns, even 
In addition, we calculate the call and put options return from day -1 to day 0 . We conjecture that if options traders hold information and can predict event window returns, conditional on a positive acquirer announcement return, investors should buy more calls and sell more puts on the acquirer's stock. In this case, we expect that the call return should be positive and the put return should be negative. However, conditional on a negative announcement return, investors should buy more puts and sell more calls, resulting in a positive return in puts and a negative return in calls. Using the bid-ask midpoint on day -1 and day 0 , we calculate the call return and the put return for each option and take the option delta-weighted average for all calls or puts of each event. We then calculate the average call or put return across all events. In untabulated results, we show that, conditional on a positive announcement CAR, call (put) options have a mean return of $12.77 \%(-7.34 \%)$ and, conditional on a negative CAR, call (put) options have a mean return of $-9.67 \%(13.88 \%)$. The results hold when we take into account of trading costs (i.e. bid-ask spread) or use trading volume as the weight. These findings suggest that although the announcement CAR does not change by a large magnitude when informed options trading measures change by one standard deviation, investors may still earn a high options return if they trade on their private information.

In sum, our main hypothesis is well supported. We find evidence that options traders do hold private information and trade on it before the announcement of an M\&A event. IV spread is positively associated with the acquirer announcement return, whereas IV skew is negatively associated with the acquirer announcement return. In addition predictability remains significant when we control for other factors that may affect the event window returns.

though the literature shows that M\&A acquirer announcement returns have a mean close to zero (about $-0.10 \%)$. 


\section{Additional tests and robustness check}

In this section, we extend our hypothesis testing in four aspects: the predictability on pseudoevents, the impact of pre-M\&A returns, the role of options liquidity, and the predictability of O/S. We then provide evidence using different variations of IV spread and IV skew as robustness check.

\section{A. Predictability on pseudo-events}

To determine whether the predictability of our informed options trading measures exists only in the information event, i.e. before the announcement of M\&A, or even in the normal period, we conduct simulations to test the predictability around M\&A events as a comparison to that in the nonevent period. We carry out simulations using three ways to select pseudo-events. First, for each sample acquirer, we randomly choose a non-M\&A announcement date and pretend that it is the actual M\&A announcement date. Second, on each actual M\&A announcement date, we randomly select a non-acquiring firm from the pool of all firms with options trading data. Finally, we pick up a non-announcement date from any non-acquirer and treat it as the actual event date. We regress the two-day $(t, t+1)$ CAR on IV spread and IV skew at $t-1$, where $t$ is the pseudo-announcement date, and control for the pre-month return and the pre-year return. The process is repeated for 1,000 times. We compute the $p$-value for IV spread (IV skew) regressions as the fraction of the number of trials with the simulated coefficient larger (smaller) than the coefficient of the actual M\&A sample. Table 5 (rows 2-4) reports the average 
coefficient and the associated $p$-value in simulations. For convenience, we also provide the coefficient based on our M\&A sample (Model 2 of Table 4) for comparison in row 1.

\section{[Table 5 about here]}

The regression coefficients for the original M\&A sample are three to four times in magnitude of those in simulations. The small $p$-values indicate that there are very few cases in which the IV spread or the IV skew has stronger predictability on normal days than on the day immediately before the M\&A announcements. These results confirm our main finding that preM\&A options trading contains private information and that our informed options trading measures do predict acquirer announcement returns. This predictability is much stronger around the M\&A event dates.

Note that our simulations also suggest that IV spread and IV skew have some predictability during the pseudo-event (or non-event) days. This finding is consistent with Cremers and Weinbaum (2010) and Xing et al. (2010) who find that IV spread and IV skew predict future stock returns in general. By comparing the regression coefficients for pseudoevents and actual M\&As, we not only confirm their findings but also show a much larger predictability around the actual M\&A announcements.

\section{B. The impact of pre-M\&A returns}

This subsection examines the impact of pre-M\&A announcement returns. We conjecture that if some informed traders also trade on their private information in the stock market or part of the M\&A information has been leaked out to the stock market before the announcement, the preevent stock return will incorporate a certain level of that information. As a result, we expect that 
the predictive power of IV spread and IV skew on acquirer announcement CAR will be reduced by a larger pre-event price change. This conjecture is consistent with the argument in Roll et al. (2010) who find a lower predictability of relative trading volume of options to stock when the pre-event return is higher. We capture this effect with the interaction terms of our options measures and pre-event CARs. The regressions are

$$
\begin{aligned}
\text { CAR }_{i,[t, t+1]} & =\beta_{0, i}+\beta_{1, i} \text { IV Spread }_{i, t-1}+\beta_{2, i} \text { IV Spread } \\
& +\gamma_{i, t-1}{\text { Control } \text { Variables }_{i}+\varepsilon_{i}} \\
\text { CAR }_{i,[t, t+1]}= & \beta_{0, i}+\beta_{1, i} \text { IV Skew }_{i, t-1, t-1]}+\beta_{2, i} \text { IV Skew }_{i, t-1} * \text { CAR }_{i,[t-3, t-1]} \\
& +\gamma_{i} \text { Control Variables }_{i}+\varepsilon_{i}
\end{aligned}
$$

where $C A R_{i,[t-3, t-1]}$ refers to the cumulative abnormal return for acquirer $i$ from day $t-3$ to $t-1$, IV spread and IV skew are $t-1$ measures of informed options trading. All control variables are defined in equation (3).

If the M\&A announcement delivers good news and the pre-event CAR is high, we expect that the positive relation between IV spread and announcement CAR will be smaller because some positive information has been incorporated into the share price before the announcement. If the pre-event return is low given a favorable M\&A event, the net effect of IV spread on acquirer announcement CAR should be even stronger. As a result, in equation (4a), $\beta_{1}$ is expected to be positive while $\beta_{2}$ is expected to be negative.

Similarly, if the M\&A event is considered to be bad news and the pre-event CAR is negative, we expect that the negative relation between IV skew and acquirer announcement CAR will be weaker due to the unfavorable information disseminated before the announcement. Thus in equation ( $4 b)$, we expect both $\beta_{1}$ and $\beta_{2}$ to be negative. 
Table 6 reports the results of the pre-event CAR. IV spread has a positive and significant prediction on acquirer announcement CARs; the interaction of IV spread and pre-event CAR is negative although insignificant (Models 1 to 3 ). However, IV skew is negatively correlated with announcement CAR, and its interaction with pre-event CAR is also negative and significant (Models 4 to 6). Overall, when the pre-announcement return has already incorporated part of the M\&A information, the predictability of our informed options trading measures will be reduced to some extent.

[Table 6 about here]

\section{The role of liquidity}

Easley et al. (1998) argue that there will be more informed trading in the options market when options are more liquid. As a natural extension of this argument, we examine whether the predictability of IV spread and IV skew is affected by the liquidity of options. We expect that their predictive power will be strengthened if liquidity in options is higher, and vice versa.

We measure options liquidity by bid-ask spread. In particular, for each option on each day, we calculate the difference between best offer price and best bid price and then divide it by the mid-point of the two. This measure serves as a proxy for the cost paid by options traders: the higher the bid-ask spread, the lower the options liquidity. We take the average bid-ask spread across all non-zero trading volume options for each firm $i$ on each day and then use the average from day $t-5$ to $t-1$ as a proxy for the acquirer's options liquidity before the M\&A event. We then interact options bid-ask spread with each of our informed options trading measures. The regressions are 


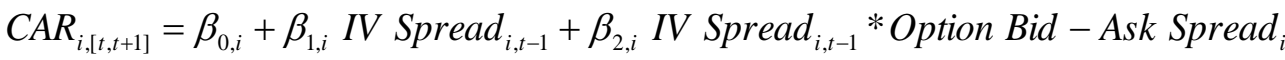

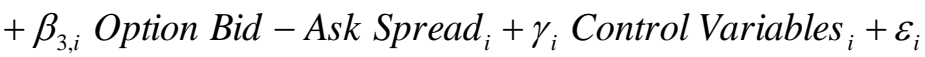

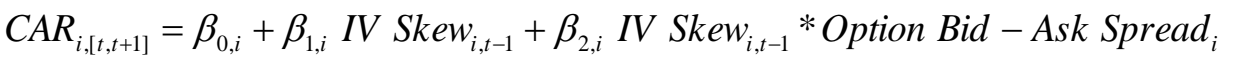

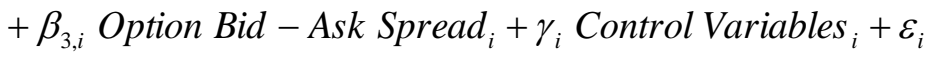

where Options Bid-Ask Spread is our options liquidity variable. We use this regression to examine the return predictability of IV spread or IV skew under different levels of options liquidity. All other variables are the same as in equation (3).

Table 7 reports the empirical results. Consistent with our expectation, the coefficient on IV Spread * Option Bid-Ask Spread is negative (Models 1 to 3), indicating that IV spread has a weaker prediction when options liquidity is lower. Similarly, the coefficient on IV Skew * Option Bid-Ask Spread is positive and significant (Models 4 to 6). It supports our argument that higher options liquidity strengthens the predictive power of IV skew, and vice versa.

[Table 7 about here]

Consistent with the findings in Easley et al. (1998) and Cremers and Weinbaum (2010), we show that liquidity plays a significant role when investors choose in which market to trade. When options liquidity is higher, informed investors may trade more actively in the options market to take advantage of high leverage and low cost. As a result, options trading contain more information about the M\&A events, and our informed options trading measures exhibit stronger predictive power on M\&A announcement returns.

D. The predictability of $\mathrm{O} / \mathrm{S}$ 
For robustness, we consider an alternative informed trading measure, the relative trading volume of options to stock (O/S), which is an unsigned volume-based option measure. ${ }^{14}$ Roll et al. (2010) show its return predictability in earnings announcement returns.

If investors hold private information on M\&A events, they are likely to trade in both the stock market and the options market prior to announcements. Due to the advantage of leverage and liquidity of options, options trading volume should increase more than stock trading volume. As a result, $\mathrm{O} / \mathrm{S}$ should increase. When the M\&A event generates good (bad) news, investors may actively buy (sell) call options or sell (buy) put options. In each case, O/S will be driven up, given that we consider trading of both call and put options at the same time. Hence, if investors trade in the options market to capitalize on their private information before M\&A announcement, pre-event O/S should positively predict absolute acquirer CARs. In addition, if a portion of the M\&A information has been reflected during the pre-event period, the pre-event CAR will have a negative impact on positive association between $\mathrm{O} / \mathrm{S}$ and acquirer announcement CARs. We conduct cross-sectional regressions as follows:

$$
\begin{aligned}
\left|\operatorname{CAR}_{i,[t, t+1]}\right| & =\beta_{0, i}+\beta_{1, i} \operatorname{Ln}(\operatorname{Sh} O / S)_{i, t-1}+\gamma_{i} \text { Control Variables }{ }_{i}+\varepsilon_{i} \\
\left|C A R_{i,[t, t+1]}\right| & =\beta_{0, i}+\beta_{1, i} \operatorname{Ln}(\operatorname{ShO} / S)_{i, t-1}+\beta_{2, i} \operatorname{Ln}(\operatorname{Sh} O / S)_{i, t-1} *\left|C A R_{i,[t-3, t-1]}\right| \\
& +\gamma_{i} \text { Control Variables }{ }_{i}+\varepsilon_{i}
\end{aligned}
$$

where the dependent variable is the absolute value of two-day $(t, t+1)$ CAR for acquirer $i$, and $\operatorname{Ln}$ (Sh O/S) is the natural logarithm of share volume O/S based on Roll et al. (2010). ${ }^{15}$ In regression

\footnotetext{
${ }^{14}$ For other volume based measures, also see Spyrou, Tsekrekos, and Siougle (2011).

${ }^{15}$ For each firm, daily share option volume is calculated as the total contracts traded in each option multiplied by 100 (each contract is for 100 shares of stock), then aggregated across all
} 
equation (7b), $\mathrm{O} / \mathrm{S}$ is interacted with the absolute value of acquirer CAR from day $t-3$ to $t-1$. All controls are defined as in equation (3).

Table 8 reports the regression results of O/S. The first two models show a positive and significant relation between the pre-event $\mathrm{O} / \mathrm{S}$ and acquirer announcement returns. A higher trading volume of options relative to stock before the M\&A announcement is associated with a larger absolute announcement return of the acquirer. In the last two models, O/S is interacted with the absolute CAR during the pre-event three days. The coefficient for this interaction term is negative, as reported in Models 3 and 4.

\section{[Table 8 about here]}

We also compute dollar volume $\mathrm{O} / \mathrm{S}(\$ \mathrm{O} / \mathrm{S})$ as the informed trading proxy. ${ }^{16}$ The regressions show results similar to using share volume O/S. Besides, we try deciles of Sh O/S and deciles of $\$ \mathrm{O} / \mathrm{S}$, and find that $\mathrm{O} / \mathrm{S}$ deciles are, in general, positively associated with acquirer's absolute CAR around announcement. ${ }^{17}$ For brevity, we do not tabulate the results.

To determine whether our informed options trading measures can predict the occurrence of M\&A event, for each acquirer we identify one non-event firm matched on size, book-to-

options traded on that stock. Share volume $\mathrm{O} / \mathrm{S}(\mathrm{Sh} \mathrm{O} / \mathrm{S})$ is the ratio of share option volume to stock trading volume on that day.

${ }^{16}$ Dollar options volume is calculated by multiplying the total number of contracts traded in each options by the average of best bid and best offer price and then multiplied by 100. Dollar stock volume equals stock price multiplied by stock trading volume. Dollar volume $\mathrm{O} / \mathrm{S}(\$ \mathrm{O} / \mathrm{S})$ is then calculated as the ratio of dollar options volume to dollar stock volume.

${ }^{17}$ See Johnson and So (2012) for deciles of O/S as informed options trading measure. 
market ratio, past one-year return, and industry. We use an M\&A dummy variable to identify whether this firm is an acquirer or a matching firm. We then regress the M\&A dummy on our informed options trading measures and control variables. Appendix Table 1 shows the logit regression results for $\mathrm{O} / \mathrm{S}$. The result suggests that the options volume increases before $\mathrm{M} \& \mathrm{~A}$ event.

In untabulated results, we also conduct the logit regressions using IV spread and IV skew as the informed trading measures. However, we do not find a significant prediction on the occurrence of M\&A for IV spread and IV skew. One possible explanation is as follows. When investors hold positive information about the M\&A event, they are likely to buy more call options. The increase of IV spread is expected to be positively correlated with the occurrence of an M\&A event with a positive return. However, if investors hold negative information and buy more put options, IV spread will decrease. In this case, a higher IV spread should be negatively related with the occurrence of an M\&A event with a negative return. Since acquirers have, on average, zero announcement return, the positive and negative prediction of IV spread on M\&A occurrence may cancel out. A similar argument applies to IV skew. As a result, we should only find a significant prediction of $\mathrm{O} / \mathrm{S}$ on an M\&A event.

In addition, if options traders are merely aware of the occurrence of M\&A events, we should not find a directional prediction of IV spread, IV skew, and O/S on the announcement CAR but should only observe an increase in options trading volume before M\&A event. The buying pressure on call or put options should not necessarily have a positive or negative correlation with the occurrence of M\&A. Investors' options trading is likely to predict the announcement return only when they possess some information on the M\&A event and have an expectation on the return. 


\section{E. Robustness check}

We perform several robustness tests on variations of our options measures. The predictability remains significant when we use deciles of IV spread and IV skew and changes in IV spread and IV skew over the previous week as well as over the previous month.

To mitigate the impact of extreme values of our informed options trading measures, we adopt deciles instead of the raw value of IV spread and IV skew in regressions. As shown in Models 1 and 4 of Table 9, deciles of IV spread and IV skew have consistent and significant prediction on acquirer announcement returns. A higher decile of IV spread indicates a higher acquirer announcement CAR whereas a higher decile of IV skew indicates a lower acquirer announcement CAR. Other variations, such as quintiles and quartiles, generate similar results.

\section{[Table 9 about here]}

In Models 2 and 5, we adopt changes in IV spread and IV skew over the previous week (i.e., the difference between day $t-1$ and the average from day $t-6$ to day $t-2$ ). Similarly, in Models 3 and 6, we adopt changes in IV spread and IV skew over the previous month (i.e., the difference between day $t-1$ and the average from day $t-23$ to day $t-2)$. Intuitively, a large and positive change in IV spread indicates that informed investors are buying increasingly more calls than puts as the M\&A announcement is approaching. It also indicates that investors may hold positive information about the event. Conversely, if IV skew increases gradually before the M\&A announcement, investors are likely to trade on negative information, and thus they purchase more OTM puts than ATM calls. Using changes in IV spread and IV skew provides consistent and significant results as shown in Table 4. 
We also conduct robustness tests by excluding M\&A events with deals valued below $\$ 10$ million (about 5\% of total observations) or below $\$ 100$ million (about 32\% of total observations). Predictability remains significant. We also mitigate the effect of small firms by dropping acquirers with market capitalization below $\$ 400$ million (about $10 \%$ of total observation), and our results still hold.

In sum, our results indicate that some informed investors trade actively in options market prior to announcements in anticipation of the M\&A events. Both the signed (IV spread and IV skew) and unsigned $(\mathrm{O} / \mathrm{S})$ informed options trading measures have significant predictive power on acquirer announcement return. Our informed option measures show stronger predictability on actual M\&A announcement days compared with non-announcement days. In addition, the predictability is affected by pre-event price change and the liquidity of options. Our results are robust to different alternative constructions of informed options trading measures.

\section{Evidence from target firms}

In the previous sections, we show that options trading contains information on M\&A acquirer CARs. To complete the study, we also analyze a smaller sample of target firms and find some supporting evidence for our main hypothesis. We follow the same sample selection procedure as that for acquirers and obtain 2,372 M\&A observations (1,990 target firms) for January 1996 to December 2010. Appendix Table 2 provides the summary statistics. Most target firms have positive announcement returns. The mean return is $16.62 \%$, which is much higher than that of acquirers. Investors regard the M\&A events as good news for target firms and expect positive returns after the mergers or acquisitions. As shown in Panel C and Panel D of Appendix Figure 1, 
target average return increases dramatically immediately before the announcement but remains relatively small on normal days. In addition, events with cash-only payment have a higher mean return than those with shares payment method. The difference is about $10 \%$. As mentioned in Section II, targets have lower liquidity and higher information asymmetry, which is one of the reasons why we focus on the acquirers in this paper.

Appendix Table 3 reports summary statistics of IV spread and IV skew for targets. Different from acquirers, targets have a slightly positive mean for IV spread, suggesting that the call option is more expensive than the put option for the matching pair. It indicates a higher demand for call options due to investors' expectation that target firms will have positive returns in near future.

To examine the general pattern of target CARs with respect to our informed options trading measures, we repeat the analysis in Table 3 by sorting the sample into quintiles based on pre-event IV spread and IV skew (Appendix Table 4). Each quintile has a significantly positive mean return (and median return) from day $t$ to $t+1$. The difference between extreme quintiles shows a consistent result with the finding in acquirers that target CAR increases with IV spread and decreases with IV skew.

Our hypothesis is that option traders hold private information on M\&A events. Target announcement return can be positively predicted by IV spread and negatively predicted by IV skew. We rerun our main regression in equation (3) using target CAR from day $t$ to $t+1$ as dependent variable and target IV spread and IV skew on day $t-1$ as independent variables separately. All control variables follow the same definitions as before except that we use target information for pre-month and pre-year return and firm characteristics. Table 10 shows that IV spread has a positive prediction by itself $\left(\beta_{1}=11.56\right)$ and with all controls $\left(\beta_{1}=1.93\right)$. IV skew 
has a negative and significant prediction by itself $\left(\beta_{1}=-19.53\right)$ and with all controls $\left(\beta_{1}=-\right.$ 15.89). The weaker results could be due to lower liquidity of options trading for targets. In general, we find some supporting evidence in target firms, which is consistent with Cao et al. (2005).

[Table 10 about here]

Although the target firms have much higher announcement returns than the acquirering firms, we focus not on the level of CAR but on the correlation between CARs and informed options trading measures for testing our informed trading hypothesis. The higher return for targets is reflected in the large intercept in Table 10. As a comparison, the intercept for acquirers,

as shown in Table 4, is much smaller and close to zero. It indicates that even though the level of acquirer CAR is small, the correlation between CAR and informed options trading measures can still be large and significant, which is reflected by the coefficients on IV spread and IV skew.

\section{Conclusion}

Previous research shows that options trading contains information on future stock returns. Some prior studies have examined time-series and cross-sectional predictions of options trading. Others employ options measures to examine corporate events, such as earnings announcements and stock splits. However, little is known about the informational content of options trading prior to M\&A events. Our paper, to our knowledge, is the first to investigate the predictability of options trading on M\&A acquirer announcement return.

Prior research argues that informed investors tend to capitalize on their private information by trading actively to take advantage of the high leverage in options. We thus posit 
that pre-event options trading contains information on M\&A acquirer announcement returns. We adopt two newly developed proxies for informed options trading: IV spread as in Cremers and Weinbaum (2010) and IV skew as in Xing et al. (2010). A larger IV spread indicates a higher demand for calls and a positive expectation on future stock returns. We find that IV spread positively predicts M\&A acquirer announcement returns. Meanwhile, a larger IV skew is a proxy for higher buying pressure on OTM puts relative to ATM calls, indicating that investors are expecting a negative return in future. Based on our hypothesis, IV skew should negatively predict M\&A acquirer announcement return, and the results are consistent with our expectation.

We further support our main hypothesis by considering the following three aspects. First, we show that the IV spread and IV skew have much stronger predictability around actual M\&A announcement days, compared with pseudo-event days. Second, we find that the predictability of informed options trading measures is related to pre-event price changes. If the pre-event return is positive (negative), the predictive power of IV spread (skew) will be reduced, and vice versa. Third, we find that predictability of options measures is higher if a firm has relatively higher option liquidity prior to M\&A announcement. If, however, option is less liquid, the predictability will be lower.

In addition, we test a variety of informed trading measures for robustness checks. For example, we adopt a volume-based proxy for informed options trading and find that a higher relative trading volume of options to stock (i.e., O/S) is associated with a higher absolute announcement return for acquirers. If information has been partially incorporated into pre-event stock prices, the announcement absolute CAR will be smaller, and the predictive power of O/S will decrease. This finding suggests that at least some investors have correctly predicted the direction of price changes around M\&A announcements. Our main results are also robust using 
other variations of IV spread and IV skew, such as the decile ranking, change from the previous week, and change from the previous month. Finally, we show that our results are not dominated by events with small deal values or firms with small market capitalizations.

In sum, M\&A acquirer announcement returns can be predicted by pre-event informed options trading measures. The predictive power concentrates around actual announcement dates. The result is affected by pre-event stock returns and is strengthened when the options trading is more liquid. Our main results hold for a smaller sample of target firms that IV spread and IV skew show some predictability on target announcement return. 


\section{Appendix: Construction of IV spread and IV skew}

\section{A. IV spread}

We employ IV spread documented in Cremers and Weinbaum (2010) as one of our proxies for informed options trading activity. To measure deviations from put-call parity, IV spread is constructed as the average difference in implied volatilities between call and put options for the same security with the same strike price and the same maturity. In particular, we compute IV spread for each firm $i$ on each day $t$ as

$$
I V \text { Spread }_{i, t}=I V_{i, t}^{\text {calls }}-I V_{i, t}^{\text {puts }}=\sum_{j=1}^{N_{i, t}} w_{j, t}^{i}\left(I V_{j, t}^{i, \text { call }}-I V_{j, t}^{i, p u t}\right)
$$

where $j$ refers to pairs of call and put options with the same strike price and the same maturity, $N_{i, t}$ is the total number of valid pairs for each stock $i$ on day $t$, and $w_{j, t}^{i}$ is the weight where we use the average open interest of call and put in each pair. $I V_{j, t}^{i}$ represents the Black and Scholes (1973) implied volatility for each call and put option.

We exclude those options with zero open interest or zero best bid price. We only keep short-term options with time-to-maturity from 10 to 60 days, because an option with its maturity longer than two months is less liquid. If investors have private information on M\&A events, they are more likely to trade on short-term options to realize profit immediately. Short-term options are thus expected to reflect more on the information embedded in pre-event options trading. We then require option volume to be positive because our aim is to study the information contained in pre-event options trading. If there is no trading on the particular option, no information should be revealed from the implied volatility. To make the filters consistent between IV spread and IV skew, we further restrict stock volume to be positive, stock price to be greater than $\$ 5$, implied 
volatility of options to be between $3 \%$ and $200 \%$, and option's average bid and ask price to be higher than $\$ 0.125$.

\section{B. IV skew}

According to Xing et al. (2010), we calculate IV skew for firm $i$ on day $t$, as the implied volatility difference between out-of-the-money (OTM) put and at-the-money (ATM) call,

$$
I V \text { Skew }_{i, t}=I V_{i, t}^{\text {OTMput }}-I V_{i, t}^{\text {ATMcall }}
$$

where $I V_{i, t}$ represents the Black and Scholes (1973) implied volatility for OTM put and ATM call option. To ensure option liquidity, we also use short-term options with time-to-expiration between 10 to 60 days. We require stock volume and option volume to be positive to eliminate those nontrading cases. We further restrict stock price to be greater than $\$ 5$, option open interest to be positive, option best bid price to be positive, implied volatility of options to be between $3 \%$ and $200 \%$, and option's average bid and ask price to be higher than $\$ 0.125$.

We define moneyness as the ratio of strike price to stock price. OTM puts are defined as put options with moneyness between 0.80 and 0.95 , and ATM calls are defined as call options with moneyness between 0.95 and 1.05. If there are multiple OTM puts and ATM calls, we select one OTM put with moneyness closest to 0.95 and one ATM call with moneyness closest to 1. In several occasions, there are put options with the same moneyness which is closest to 0.95 . We keep the one with the highest open interest, or if open interests are the same, we keep the one with the highest stock trading volume. We follow the same selection criteria for ATM calls. In this approach, we come up with one skew measure for each firm $\mathrm{i}$ on each day $\mathrm{t}$. 


\section{References}

Arnold, T.; G. Erwin; L. Nail; and T. Nixon. "Do Option Markets Substitute for Stock Markets?" Evidence from Trading on Anticipated Tender Offer Announcements. International Review of Financial Analysis, 15 (2006), 247-255.

Back, K. “Asymmetric Information and Options.” Review of Financial Studies, 6 (1993), 435472.

Bali, T. G., and A. Hovakimian. "Volatility Spreads and Expected Stock Returns." Management Science, 55 (2009), 1797-1812.

Bester, C. A.; V. H. Martinez; and I. Rosu. "Option Prices and the Probability of Success of Cash Mergers.” Working paper (2011).

Black, F., and M. Scholes. "The Pricing of Options and Corporate Liabilities." Journal of Political Economy, 81 (1973), 637-654.

Bollen, N., and R. Whaley. "Does Net Buying Pressure Affect the Shape of Implied Volatility Functions?" Journal of Finance, 59 (2004), 711-753.

Cao, C.; Z. Chen; and J. Griffin. "Informational Content of Option Volume Prior to Takeovers." Journal of Business, 78 (2005), 1073-1109.

Cao, H. "The Effect of Derivative Assets on Information Acquisition and Price Behavior in a Rational Expectations Equilibrium.” Review of Financial Studies, 12 (1999), 131-163.

Chan, K.; Y. P. Chung; and W. Fong. "The Informational Role of Stock and Option Volume." Review of Financial Studies, 15 (2002), 1049-1075. 
Cremers, M., and D. Weinbaum. "Deviations from Put-Call Parity and Stock Return Predictability." Journal of Financial and Quantitative Analysis, 45 (2010), 335-367.

Easley, D.; M. O'Hara; and P. S. Srinivas. "Option Volume and Stock Prices: Evidence on Where Informed Traders Trade.” Journal of Finance, 53 (1998), 431-465.

Fuller, K.; J. Netter; and M. Stegemoller. "What Do Returns to Acquiring Firms Tell Us? Evidence from Firms That Make Many Acquisitions." Journal of Finance, 57 (2002), 1763-1793.

Graham, J. R.; M. L. Lemmon; and J. G. Wolf. “Does Corporate Diversification Destroy Value?” Journal of Finance, 57 (2002), 695-720.

Harford, J.; D. Jenter; and K. Li. "Institutional Cross-Holdings and Their Effect on Acquisition Decisions." Journal of Financial Economics, 99 (2011), 27-39.

Hazelkorn, T.; M. Zenner; and A. Shivdasani. "Creating Value with Mergers and Acquisitions." Journal of Applied Corporate Finance, 16 (2004), 81-90.

Jin, W.; J. Livnat; and Y. Zhang. “Option Prices Leading Equity Prices: Do Option Traders Have an Information Advantage?” Journal of Accounting Research, 50 (2012), 401-432.

Johnson, T. L., and E. C. So. "The Option to Stock Volume Ratio and Future Returns.” Journal of Financial Economics, 106 (2012), 262-286.

Lin, T. C.; X. Lu; and J. Driessen. "Why Do Option Prices Predict Stock Returns?” Working paper (2013).

Loughran, T., and A. M. Vijh. "Do Long-Term Shareholders Benefit From Corporate Acquisitions?” Journal of Finance, 52 (1997), 1765-1790. 
Mara, F.; J. McConnell; and D. Stolin. "Returns to Acquirers of Listed and Unlisted Targets." Journal of Financial and Quantitative Analysis, 41 (2006), 197-220.

Moeller, S. B.; F. P. Schlingemann; and R. M. Stulz. "Firm Size and the Gains from Acquisitions." Journal of Financial Economics, 73 (2004), 201-228.

Moeller, S. B.; F. P. Schlingemann; and R. M. Stulz. "Wealth Destruction on a Massive Scale: A Study of Acquiring Firm Returns in the Merger Wave of the Late 1990s." Journal of Finance, 60 (2005), 757-782.

Muravyev, D.; N. D. Pearson; and J. P. Broussard. "Is There Price Discovery in Equity Options?" Journal of Financial Economics, 107 (2013), 259-283.

Netter, J. M.; M. A. Stegemoller; and M. B. Wintoki. "Implications of Data Screens on Merger and Acquisition Analysis: A Large Sample Study of Mergers and Acquisitions from 1992-2009.” Review of Financial Studies, 24 (2011), 2242-2285.

Pan, J., and A. M. Poteshman. "The Information in Option Volume for Future Stock Prices." Review of Financial Studies, 19 (2006), 871-908.

Roll, R.; E. Schwartz; and A. Subrahmanyam. "O/S: The Relative Trading Activity in Options and Stock." Journal of Financial Economics, 96 (2010), 1-17.

Savor, P. G., and Q. Lu. "Do Stock Mergers Create Value for Acquirers?" Journal of Finance, 64 (2009), 1061-1097.

Skinner, D. J. "Do Options Markets Improve Informational Efficiency?" Contemporary Accounting Research, 14 (1997), 193-201. 
Spyrou, S.; A. Tsekrekos; and G. Siougle. "Informed Trading around Merger and Acquisition Announcements: Evidence from the UK Equity and Options Markets." Journal of Futures Markets, 31 (2011), 703-726.

Van Buskirk, A. "Volatility Skew, Earnings Announcements, and the Predictability of Crashes." Working paper (2011).

White, H. "A Heteroskedasticity-Consistent Covariance Matrix Estimator and a Direct Test for Heteroskedasticity.” Econometrica, 48 (1980), 817-838.

Xing, Y.; X. Zhang; and R. Zhao. "What Does the Individual Option Volatility Smirk Tell Us about Future Equity Returns?” Journal of Financial and Quantitative Analysis, 45 (2010), $641-662$. 


\section{Table 1. Summary Statistics for Merger and Acquisition Events: Acquirers}

This table presents summary statistics for acquirers in merger and acquisition (M\&A) events. Panel A shows the number of events and acquirers in each year. Panel B shows summary statistics on acquirer firm characteristics. CAR is the cumulative abnormal return from day $t$ to $t+1$ where day $t$ is the announcement date. Option bid-ask spread is the pre-M\&A five-day average bid-ask spread across all options traded on the firm's equity. Analyst coverage equals to the number of IBES analyst recommendations in the month before M\&A. Size is the natural logarithm of market capitalization in millions on the day before M\&A announcement. Age is the number of years that a stock has been covered in CRSP before the M\&A announcement. Idiosyncratic volatility is the standard deviation of the residuals from the Fama-French three factor model with daily returns in the pre-M\&A 12 months. Std represents standard deviation. Min represents minimum value, and Max represents maximum value. All variables except CAR are winsorized at $1 \%$ and $99 \%$ level. 


\begin{tabular}{lcc}
\hline \multicolumn{3}{c}{ Panel A. M\&A Events by Year } \\
\hline Year & Number of M\&A Events & Number of Firms \\
\hline 1996 & 426 & 301 \\
1997 & 533 & 377 \\
1998 & 669 & 455 \\
1999 & 638 & 440 \\
2000 & 652 & 454 \\
2001 & 391 & 304 \\
2002 & 342 & 284 \\
2003 & 344 & 291 \\
2004 & 403 & 333 \\
2005 & 422 & 354 \\
2006 & 453 & 371 \\
2007 & 511 & 409 \\
2008 & 471 & 367 \\
2009 & 362 & 293 \\
2010 & 430 & 351 \\
\hline $1996-2010$ & 7,047 & 2,439 \\
\hline
\end{tabular}

Panel B: Characteristics of acquirers

\begin{tabular}{lrrrrrrr}
\hline & Mean & \multicolumn{1}{c}{ Std } & Min & Q1 & Median & \multicolumn{1}{c}{ Q3 } & \multicolumn{1}{c}{ Max } \\
\cline { 2 - 7 } CAR (\%) & -0.10 & 6.52 & -71.46 & -2.48 & -0.08 & 2.32 & 71.39 \\
Option bid-ask spread & 0.25 & 0.18 & 0.06 & 0.15 & 0.20 & 0.29 & 1.19 \\
Analyst coverage & 12.15 & 8.43 & 1.00 & 6.00 & 10.00 & 17.00 & 38.00 \\
Size & 8.14 & 1.73 & 4.77 & 6.85 & 7.93 & 9.27 & 12.34 \\
Age & 20.02 & 19.72 & 0.54 & 5.50 & 13.05 & 27.84 & 81.14 \\
Idiosyncratic volatility & 0.03 & 0.01 & 0.01 & 0.02 & 0.02 & 0.03 & 0.07 \\
\hline
\end{tabular}




\section{Table 2. Summary Statistics for Option Measures}

This table shows the summary statistics for the two options measures we adopt, i.e. implied volatility (IV) spread and implied volatility (IV) skew. The details for each year are presented in Panel A and B, with the statistics for the whole sample period in the last row of each panel. 


\begin{tabular}{lcccccccc}
\hline \multicolumn{1}{c}{ Panel A. IV Spread Summary Statistics by Year } \\
\hline Year & No. Obs. & MEAN & STD & MIN & Q1 & MEDIAN & Q3 & MAX \\
1996 & 133 & 0.0010 & 0.0569 & -0.1578 & -0.0306 & -0.0076 & 0.0186 & 0.1933 \\
1997 & 164 & -0.0110 & 0.0556 & -0.1954 & -0.0406 & -0.0133 & 0.0154 & 0.2500 \\
1998 & 220 & -0.0169 & 0.0585 & -0.4327 & -0.0353 & -0.0095 & 0.0130 & 0.1207 \\
1999 & 270 & -0.0102 & 0.0560 & -0.2514 & -0.0265 & -0.0072 & 0.0116 & 0.2534 \\
2000 & 329 & -0.0208 & 0.0912 & -1.0314 & -0.0338 & -0.0115 & 0.0082 & 0.3468 \\
2001 & 172 & -0.0128 & 0.0416 & -0.2376 & -0.0253 & -0.0085 & 0.0064 & 0.1191 \\
2002 & 120 & -0.0087 & 0.0287 & -0.0969 & -0.0171 & -0.0056 & 0.0050 & 0.0922 \\
2003 & 140 & -0.0034 & 0.0276 & -0.0989 & -0.0151 & -0.0049 & 0.0047 & 0.1493 \\
2004 & 166 & -0.0052 & 0.0219 & -0.0762 & -0.0141 & -0.0047 & 0.0037 & 0.0833 \\
2005 & 175 & -0.0105 & 0.0359 & -0.2865 & -0.0155 & -0.0038 & 0.0037 & 0.0726 \\
2006 & 219 & -0.0045 & 0.0300 & -0.2135 & -0.0107 & -0.0006 & 0.0064 & 0.1616 \\
2007 & 283 & -0.0082 & 0.0254 & -0.1426 & -0.0145 & -0.0059 & 0.0041 & 0.0842 \\
2008 & 265 & -0.0046 & 0.0565 & -0.2645 & -0.0171 & -0.0038 & 0.0106 & 0.5431 \\
2009 & 207 & -0.0099 & 0.0410 & -0.2372 & -0.0179 & -0.0062 & 0.0053 & 0.1618 \\
2010 & 213 & -0.0036 & 0.0249 & -0.1347 & -0.0122 & -0.0034 & 0.0074 & 0.0992 \\
\hline $1996-$ & 3,076 & -0.0093 & 0.0505 & -1.0314 & -0.0207 & -0.0058 & 0.0075 & 0.5431 \\
2010 & & & & & & & & \\
\hline
\end{tabular}

Panel B. IV Skew Summary Statistics by Year

\begin{tabular}{|c|c|c|c|c|c|c|c|c|}
\hline Year & No. Obs. & MEAN & STD & MIN & Q1 & MEDIAN & Q3 & MAX \\
\hline 1996 & 75 & 0.0324 & 0.0612 & -0.1154 & 0.0020 & 0.0301 & 0.0533 & 0.2565 \\
\hline 1997 & 95 & 0.0388 & 0.0552 & -0.1497 & 0.0025 & 0.0310 & 0.0687 & 0.2103 \\
\hline 1998 & 135 & 0.0397 & 0.0540 & -0.0937 & 0.0058 & 0.0314 & 0.0680 & 0.3976 \\
\hline 1999 & 192 & 0.0284 & 0.0471 & -0.1484 & 0.0066 & 0.0259 & 0.0490 & 0.2812 \\
\hline 2000 & 246 & 0.0368 & 0.0897 & -0.2006 & 0.0042 & 0.0240 & 0.0533 & 1.0071 \\
\hline 2001 & 127 & 0.0600 & 0.0554 & -0.0520 & 0.0289 & 0.0495 & 0.0770 & 0.3422 \\
\hline 2002 & 80 & 0.0696 & 0.0516 & -0.0081 & 0.0357 & 0.0607 & 0.0858 & 0.2726 \\
\hline 2003 & 95 & 0.0595 & 0.0354 & -0.0180 & 0.0345 & 0.0535 & 0.0760 & 0.2283 \\
\hline 2004 & 88 & 0.0437 & 0.0285 & -0.0139 & 0.0238 & 0.0385 & 0.0562 & 0.1738 \\
\hline 2005 & 91 & 0.0453 & 0.0330 & -0.0221 & 0.0187 & 0.0420 & 0.0595 & 0.1602 \\
\hline 2006 & 117 & 0.0321 & 0.0330 & -0.1264 & 0.0171 & 0.0276 & 0.0419 & 0.1630 \\
\hline 2007 & 179 & 0.0385 & 0.0302 & -0.0331 & 0.0204 & 0.0346 & 0.0535 & 0.1862 \\
\hline 2008 & 188 & 0.0491 & 0.0502 & -0.1483 & 0.0216 & 0.0423 & 0.0630 & 0.3167 \\
\hline 2009 & 153 & 0.0514 & 0.0430 & -0.0813 & 0.0289 & 0.0454 & 0.0643 & 0.3599 \\
\hline 2010 & 157 & 0.0423 & 0.0278 & -0.1035 & 0.0293 & 0.0395 & 0.0530 & 0.1494 \\
\hline $\begin{array}{l}1996- \\
2010\end{array}$ & 2,018 & 0.0432 & 0.0527 & -0.2006 & 0.0184 & 0.0369 & 0.0603 & 1.0071 \\
\hline
\end{tabular}




\section{Table 3. Acquirer Announcement Returns Sorted by Implied Volatility Spread and Implied Volatility Skew}

This table shows the two-day $(0,+1)$ acquirer cumulative abnormal return $(\mathrm{CAR})$ around merger and acquisition announcements sorted by quintiles of implied volatility (IV) spread and IV skew measured at day $t-1$. For each quintile, we report mean IV spread, mean CAR (in \%) and median CAR (in \%). In parentheses, we show $t$-statistics for mean CAR. For median CAR, we conduct Wilcoxon signed-rank test and show p-value in brackets. ${ }^{* *}, * *$, and $*$ indicate significance at the $1 \%, 5 \%$, and $10 \%$ level, respectively. The difference between the highest (quintile 5) and the lowest (quintile 1) IV spread or IV skew groups is presented in the last column.

\begin{tabular}{|c|c|c|c|c|c|c|}
\hline & 1 (Low) & 2 & 3 & 4 & 5 (High) & High-Low \\
\hline \multicolumn{7}{|c|}{ Sorted by IV Spread } \\
\hline Mean IV Spread & -0.068 & -0.017 & -0.006 & 0.004 & 0.040 & \\
\hline Mean CAR & $\begin{array}{c}-0.82 * * * \\
(-2.74)\end{array}$ & $\begin{array}{c}-0.22 \\
(-0.90)\end{array}$ & $\begin{array}{l}-0.42 * \\
(-1.82)\end{array}$ & $\begin{array}{c}-0.28 \\
(-1.37)\end{array}$ & $\begin{array}{c}0.85 * * * \\
(3.10)\end{array}$ & $\begin{array}{c}1.67 * * * \\
(4.11)\end{array}$ \\
\hline Median CAR & $\begin{array}{c}-0.59 * * * \\
{[0.00]}\end{array}$ & $\begin{array}{l}-0.03 \\
{[0.30]}\end{array}$ & $\begin{array}{l}-0.13 \\
{[0.18]}\end{array}$ & $\begin{array}{c}0.06 \\
{[0.74]}\end{array}$ & $\begin{array}{c}0.41 * * * \\
{[0.00]}\end{array}$ & $\begin{array}{c}1.00 * * * \\
{[0.00]}\end{array}$ \\
\hline \multicolumn{7}{|c|}{ Sorted by IV Skew } \\
\hline Mean IV Skew & -0.010 & 0.022 & 0.037 & 0.055 & 0.111 & \\
\hline Mean CAR & $\begin{array}{c}0.45 \\
(1.11)\end{array}$ & $\begin{array}{c}-0.04 \\
(-0.15)\end{array}$ & $\begin{array}{c}-0.24 \\
(-1.08)\end{array}$ & $\begin{array}{c}-0.55 * * \\
(-2.08)\end{array}$ & $\begin{array}{l}-0.57 * \\
(-1.76)\end{array}$ & $\begin{array}{c}-1.02 * * \\
(-1.96)\end{array}$ \\
\hline Median CAR & $\begin{array}{c}0.32 \\
{[0.13]}\end{array}$ & $\begin{array}{c}0.17 \\
{[0.62]}\end{array}$ & $\begin{array}{l}-0.11 \\
{[0.30]}\end{array}$ & $\begin{array}{c}-0.19 * * \\
{[0.03]}\end{array}$ & $\begin{array}{c}-0.46 * * \\
{[0.04]}\end{array}$ & $\begin{array}{c}-0.78 * * * \\
{[0.01]}\end{array}$ \\
\hline
\end{tabular}




\section{Table 4. Cross-Sectional Regressions of Acquirer Announcement Returns on Implied Volatility Spread and Implied Volatility Skew}

This table presents the cross-sectional regressions of acquirer announcement returns on implied volatility (IV) spread and IV skew and control variables. The dependent variable is the two-day $(t, t+1)$ acquirer cumulative abnormal return (CAR) around the M\&A announcement date $t$. The CRSP value-weighted market return has been used as the benchmark when calculating the abnormal returns. In Panel $\mathrm{A}$, the independent variables include day $t-1$ IV spread, which is calculated based on Cremers and Weinbaum (2010). Panel B uses day $t-1$ IV skew, which is calculated based on Xing et al. (2010). Pre-month return and Pre-year return are buy-and-hold returns compounding over pre-event one month and pre-event 2 to 12 months, respectively. Successful equals 1 if the merger or acquisition is successfully completed, and zero otherwise. Takeover equals 1 if the event is identified as an "acquisition of majority interest" instead of a "merger" in SDC, and zero otherwise. Hostile equals 1 if the event is identified as "hostile" in SDC, and zero otherwise. Rumor equals 1 if there is a pre-event rumor, and zero otherwise. Cash equals 1 if the primary payment is cash, and zero otherwise. Size and book-to-market ratio (B/M) are in natural logarithm. CARs are expressed in percentage. We compute $t$-statistics based on White's (1980) heteroskedasticity robust standard errors. ***, **, and * indicate significance at the $1 \%, 5 \%$, and $10 \%$ level, respectively. 


\begin{tabular}{|c|c|c|c|c|c|}
\hline \multicolumn{6}{|c|}{ Panel A. IV Spread } \\
\hline Model & 1 & 2 & 3 & 4 & 5 \\
\hline IV Spread & $\begin{array}{l}13.00 * * * \\
(3.75)\end{array}$ & $\begin{array}{l}13.14 * * * \\
(3.78)\end{array}$ & $\begin{array}{l}13.41 * * * \\
(3.87)\end{array}$ & $\begin{array}{l}14.06^{* * * *} \\
(4.10)\end{array}$ & $\begin{array}{l}13.85 * * * \\
(4.03)\end{array}$ \\
\hline Pre-month Return & & $\begin{array}{c}0.59 \\
(0.56)\end{array}$ & $\begin{array}{c}0.69 \\
(0.66)\end{array}$ & $\begin{array}{c}0.59 \\
(0.55)\end{array}$ & $\begin{array}{c}0.54 \\
(0.50)\end{array}$ \\
\hline Pre-year Return & & $\begin{array}{c}0.05 \\
(0.36)\end{array}$ & $\begin{array}{c}0.08 \\
(0.59)\end{array}$ & $\begin{array}{c}0.01 \\
(0.07)\end{array}$ & $\begin{array}{c}-0.01 \\
(-0.10)\end{array}$ \\
\hline Successful & & & $\begin{array}{c}0.14 \\
(0.48)\end{array}$ & $\begin{array}{c}0.12 \\
(0.41)\end{array}$ & $\begin{array}{c}0.15 \\
(0.54)\end{array}$ \\
\hline Takeover & & & $\begin{array}{l}1.07 * * * \\
(4.42)\end{array}$ & $\begin{array}{l}1.22^{* * * *} \\
(5.11)\end{array}$ & $\begin{array}{l}1.24 * * * \\
(5.14)\end{array}$ \\
\hline Hostile & & & $\begin{array}{c}-1.91 * \\
(-1.76)\end{array}$ & $\begin{array}{c}-1.82 * \\
(-1.68)\end{array}$ & $\begin{array}{c}-1.64 \\
(-1.52)\end{array}$ \\
\hline Rumor & & & $\begin{array}{c}0.31 \\
(0.88)\end{array}$ & $\begin{array}{l}0.71 * * \\
(2.04)\end{array}$ & $\begin{array}{c}0.64 * \\
(1.79)\end{array}$ \\
\hline Cash & & & $\begin{array}{c}0.45^{*} \\
(1.90)\end{array}$ & $\begin{array}{l}0.53 * * \\
(2.30)\end{array}$ & $\begin{array}{l}0.50 * * \\
(2.15)\end{array}$ \\
\hline Size & & & & $\begin{array}{l}-0.26 * * * \\
(-3.46)\end{array}$ & $\begin{array}{l}-0.26 * * * \\
(-3.30)\end{array}$ \\
\hline $\mathrm{B} / \mathrm{M}$ & & & & $\begin{array}{c}-0.20 \\
(-1.64)\end{array}$ & $\begin{array}{c}-0.19 \\
(-1.45)\end{array}$ \\
\hline Year \& Industry Control & & & & & Yes \\
\hline Intercept & $\begin{array}{c}-0.06 \\
(-0.48)\end{array}$ & $\begin{array}{c}-0.09 \\
(-0.77)\end{array}$ & $\begin{array}{c}-0.55^{*} \\
(-1.83)\end{array}$ & $\begin{array}{l}1.53 * * \\
(2.05)\end{array}$ & $\begin{array}{c}2.33 \\
(0.97)\end{array}$ \\
\hline $\bar{N}$ & 3,076 & 3,076 & 3,076 & 3,076 & 3,076 \\
\hline Adj. $R^{2}$ & 0.01 & 0.01 & 0.01 & 0.02 & 0.02 \\
\hline
\end{tabular}


Table 4 (continued)

\begin{tabular}{|c|c|c|c|c|c|}
\hline \multicolumn{6}{|c|}{ Panel B. IV Skew } \\
\hline Model & 1 & 2 & 3 & 4 & 5 \\
\hline \multirow{2}{*}{ IV Skew } & $-9.53 * * *$ & $-9.86 * * *$ & $-9.72 * * *$ & $-9.76 * * *$ & $-9.51^{* * * *}$ \\
\hline & $(-2.59)$ & $(-2.71)$ & $(-2.68)$ & $(-2.69)$ & $(-2.58)$ \\
\hline \multirow[t]{2}{*}{ Pre-month Return } & & 0.58 & 0.68 & 0.37 & 0.47 \\
\hline & & $(0.45)$ & $(0.52)$ & $(0.28)$ & $(0.36)$ \\
\hline \multirow[t]{2}{*}{ Pre-year Return } & & -0.13 & -0.09 & -0.21 & -0.20 \\
\hline & & $(-0.75)$ & $(-0.53)$ & $(-1.16)$ & $(-1.05)$ \\
\hline \multirow[t]{2}{*}{ Successful } & & & 0.10 & 0.05 & 0.11 \\
\hline & & & $(0.28)$ & $(0.14)$ & $(0.30)$ \\
\hline \multirow[t]{2}{*}{ Takeover } & & & $0.95^{* * *}$ & $1.11 * * *$ & $1.16^{* * *}$ \\
\hline & & & $(3.22)$ & $(3.79)$ & (3.87) \\
\hline \multirow[t]{2}{*}{ Hostile } & & & $-3.14 * *$ & $-3.06^{* *}$ & $-3.09 * *$ \\
\hline & & & $(-2.22)$ & $(-2.17)$ & $(-2.18)$ \\
\hline \multirow[t]{2}{*}{ Rumor } & & & 0.27 & 0.56 & 0.51 \\
\hline & & & $(0.66)$ & $(1.42)$ & $(1.25)$ \\
\hline \multirow[t]{2}{*}{ Cash } & & & 0.23 & 0.29 & 0.27 \\
\hline & & & $(0.78)$ & $(0.99)$ & $(0.91)$ \\
\hline \multirow[t]{2}{*}{ Size } & & & & $-0.21 * *$ & $-0.22 * *$ \\
\hline & & & & $(-1.99)$ & $(-1.96)$ \\
\hline \multirow[t]{2}{*}{$\mathrm{B} / \mathrm{M}$} & & & & $-0.28 *$ & $-0.33 *$ \\
\hline & & & & $(-1.82)$ & $(-1.91)$ \\
\hline Year \& Industry Control & & & & & Yes \\
\hline \multirow{2}{*}{ Intercept } & 0.22 & 0.29 & -0.05 & 1.57 & 2.46 \\
\hline & (1.01) & (1.29) & $(-0.12)$ & (1.40) & $(0.70)$ \\
\hline $\bar{N}$ & 2,018 & 2,018 & 2,018 & 2,018 & 2,018 \\
\hline Adj. $R^{2}$ & 0.01 & 0.01 & 0.01 & 0.01 & 0.01 \\
\hline
\end{tabular}




\section{Table 5. Regressions of Pseudo-Merger and Acquisition Events}

This table shows the coefficients of implied volatility (IV) spread and IV skew in regressions of acquirer announcement returns based on simulations. For easy comparisons with simulation results, the first row shows the coefficients based on our original M\&A sample, controlling for the pre-month return and the pre-year return (i.e., Model 2 in Table 4). In the second row, for each acquirer in our sample, we randomly choose a non-announcement date as its pseudoannouncement date. In the third row, on each M\&A announcement date in our sample, we randomly choose a non-acquiring firm, as a pseudo-acquirer, from the pool of all firms with options trading. In the last row, we randomly choose a non-acquirer on a non-announcement date from the pool of all optioned firms on all days during the sample period, as a pseudo acquirer on a pseudo-announcement date. We regress the two-day $(t, t+1)$ CAR on IV spread and IV skew measured at $t-1$, where $t$ is the pseudo-announcement date, controlling for the pre-month return and the pre-year return. The process is repeated for 1,000 times. The table (rows 2-4) shows the average coefficient of pseudo-events in simulations. The significance is measured by the $p$-value reported in bracket, defined as the number of trials with the simulated coefficient of IV spread (IV skew) larger (smaller) than the actual M\&A sample coefficient, then divided by 1,000.

\begin{tabular}{lcc}
\hline & IV Spread & IV Skew \\
\hline $\begin{array}{l}\text { Original sample for acquirers on actual } \\
\text { announcement dates }\end{array}$ & 13.14 & -9.86 \\
& & \\
Acquirers on non-announcement dates & 4.45 & -2.32 \\
& {$[0.003]$} & {$[0.003]$} \\
Non-acquirers on actual announcement dates & 3.91 & -2.49 \\
& {$[0.003]$} & {$[0.008]$} \\
Non-acquirers on non-announcement dates & 3.34 & -1.85 \\
& {$[0.000]$} & {$[0.001]$} \\
\hline
\end{tabular}




\section{Table 6. The Impact of Pre-Merger and Acquisition Returns}

This table shows the cross-sectional regressions of two-day $(t, t+1)$ acquirer cumulative abnormal return (CAR) around merger and acquisition announcements on day $t-1$ of implied volatility (IV) spread and IV skew, and their interactions with pre-announcement return. $\mathrm{CAR}_{\mathrm{i}, \text { [t- }}$ $3, \mathrm{t}-1]$ measures the cumulative abnormal return from day $t-3$ to $t-1$. All other control variables are the same as in Table 4. Models 1 to 3 report results for IV spread and Models 4 to 6 are for IV skew. CARs are expressed in percentage. We compute $t$-statistics based on White's (1980) heteroskedasticity robust standard errors. $* * *, *$, and * indicate significance at the $1 \%, 5 \%$, and $10 \%$ level, respectively. 


\begin{tabular}{|c|c|c|c|c|c|c|}
\hline Model & 1 & 2 & 3 & 4 & 5 & 6 \\
\hline IV Spread & $\begin{array}{c}13.13^{* * * *} \\
(3.70)\end{array}$ & $\begin{array}{c}14.17 * * * \\
(4.03)\end{array}$ & $\begin{array}{c}13.96 * * * \\
(3.96)\end{array}$ & & & \\
\hline IV Spread $^{*} \mathrm{CAR}_{\mathrm{i},[\mathrm{t}-3, \mathrm{t}-1]}$ & $\begin{array}{l}-0.10 \\
(-0.33)\end{array}$ & $\begin{array}{l}-0.09 \\
(-0.31)\end{array}$ & $\begin{array}{l}-0.10 \\
(-0.32)\end{array}$ & & & \\
\hline IV Skew & & & & $\begin{array}{l}-8.50^{* *} \\
(-2.23)\end{array}$ & $\begin{array}{l}-8.47 * * \\
(-2.25)\end{array}$ & $\begin{array}{l}-8.25^{* *} \\
(-2.15)\end{array}$ \\
\hline IV Skew*CAR $_{\mathrm{i},[\mathrm{t}-3, \mathrm{t}-1]}$ & & & & $\begin{array}{l}-0.44 \\
(-1.60)\end{array}$ & $\begin{array}{l}-0.53^{*} \\
(-1.81)\end{array}$ & $\begin{array}{l}-0.50^{*} \\
(-1.70)\end{array}$ \\
\hline Pre-month Return & & $\begin{array}{r}0.57 \\
(0.54)\end{array}$ & $\begin{array}{c}0.52 \\
(0.49)\end{array}$ & & $\begin{array}{c}0.60 \\
(0.46)\end{array}$ & $\begin{array}{c}0.69 \\
(0.52)\end{array}$ \\
\hline Pre-year Return & & $\begin{array}{c}0.01 \\
(0.05)\end{array}$ & $\begin{array}{l}-0.02 \\
(-0.11)\end{array}$ & & $\begin{array}{l}-0.20 \\
(-1.07)\end{array}$ & $\begin{array}{l}-0.19 \\
(-1.00)\end{array}$ \\
\hline Successful & & $\begin{array}{c}0.12 \\
(0.41)\end{array}$ & $\begin{array}{c}0.16 \\
(0.54)\end{array}$ & & $\begin{array}{c}0.05 \\
(0.16)\end{array}$ & $\begin{array}{c}0.11 \\
(0.31)\end{array}$ \\
\hline Takeover & & $\begin{array}{c}1.22 * * * \\
(5.12)\end{array}$ & $\begin{array}{c}1.24 * * * \\
(5.14)\end{array}$ & & $\begin{array}{c}1.14 * * * \\
(3.89)\end{array}$ & $\begin{array}{c}1.19^{* * * *} \\
(3.96)\end{array}$ \\
\hline Hostile & & $\begin{array}{l}-1.82^{*} \\
(-1.68)\end{array}$ & $\begin{array}{l}-1.64 \\
(-1.52)\end{array}$ & & $\begin{array}{l}-3.12 * * \\
(-2.20)\end{array}$ & $\begin{array}{l}-3.15^{* *} \\
(-2.22)\end{array}$ \\
\hline Rumor & & $\begin{array}{l}0.71 * * \\
(2.04)\end{array}$ & $\begin{array}{c}0.63^{*} \\
(1.78)\end{array}$ & & $\begin{array}{c}0.59 \\
(1.49)\end{array}$ & $\begin{array}{c}0.54 \\
(1.33)\end{array}$ \\
\hline Cash & & $\begin{array}{l}0.53 * * \\
(2.30)\end{array}$ & $\begin{array}{l}0.50^{* *} \\
(2.14)\end{array}$ & & $\begin{array}{c}0.27 \\
(0.92)\end{array}$ & $\begin{array}{c}0.26 \\
(0.86)\end{array}$ \\
\hline Size & & $\begin{array}{c}-0.26 * * * \\
(-3.45)\end{array}$ & $\begin{array}{c}-0.26 * * * \\
(-3.30)\end{array}$ & & $\begin{array}{l}-0.22 * * \\
(-2.11)\end{array}$ & $\begin{array}{l}-0.23^{* *} \\
(-2.07)\end{array}$ \\
\hline $\mathrm{B} / \mathrm{M}$ & & $\begin{array}{l}-0.20^{*} \\
(-1.67)\end{array}$ & $\begin{array}{l}-0.19 \\
(-1.49)\end{array}$ & & $\begin{array}{l}-0.28^{*} \\
(-1.81)\end{array}$ & $\begin{array}{l}-0.32^{*} \\
(-1.86)\end{array}$ \\
\hline Year \& Industry Control & & & Yes & & & Yes \\
\hline Intercept & $\begin{array}{l}-0.06 \\
(-0.51)\end{array}$ & $\begin{array}{l}1.52 * * \\
(2.03)\end{array}$ & $\begin{array}{c}2.33 \\
(0.97)\end{array}$ & $\begin{array}{c}0.20 \\
(0.89)\end{array}$ & $\begin{array}{c}1.64 \\
(1.46)\end{array}$ & $\begin{array}{l}2.51 \\
(0.72)\end{array}$ \\
\hline$N$ & 3,076 & 3,076 & 3,076 & 2,018 & 2,018 & 2,018 \\
\hline Adj. $R^{2}$ & 0.01 & 0.02 & 0.02 & 0.01 & 0.01 & 0.01 \\
\hline
\end{tabular}




\section{Table 7. The Role of Options Liquidity}

This table presents the cross-sectional regressions of two-day $(t, t+1)$ acquirer cumulative abnormal return (CARs) around merger and acquisition announcements on day $t-1$ of implied volatility (IV) spread and IV skew, and their interactions with options liquidity measure. We use the bid-ask spread (best offer minus best bid, divided by the average of the two) to measure the liquidity of an option. For each day, we calculate the options bid-ask spread for all non-zero trading options and then take the average of pre-event five days. All control variables are the same as in Table 4. Models 1 to 3 are for IV spread and Models 4 to 6 are for IV skew. CARs are expressed in percentage. We compute $t$-statistics (in parentheses) based on White's (1980) heteroskedasticity robust standard errors. $* * *, * *$, and $*$ indicate significance at the $1 \%, 5 \%$, and $10 \%$ level, respectively. 


\begin{tabular}{|c|c|c|c|c|c|c|}
\hline Model & 1 & 2 & 3 & 4 & 5 & 6 \\
\hline IV Spread & $\begin{array}{l}16.41 * * \\
(2.37)\end{array}$ & $\begin{array}{c}18.28 * * * \\
(2.63)\end{array}$ & $\begin{array}{c}18.31 * * * \\
(2.61)\end{array}$ & & & \\
\hline $\begin{array}{l}\text { IV Spread*Options } \\
\text { Bid-Ask Spread }\end{array}$ & $\begin{array}{l}-15.66 \\
(-0.57)\end{array}$ & $\begin{array}{l}-19.29 \\
(-0.69)\end{array}$ & $\begin{array}{l}-20.35 \\
(-0.73)\end{array}$ & & & \\
\hline IV Skew & & & & $\begin{array}{c}- \\
23.92 * * * \\
(-3.62)\end{array}$ & $\begin{array}{c}- \\
23.59 * * * \\
(-3.66)\end{array}$ & $\begin{array}{c}- \\
23.98^{* * * *} \\
(-3.66)\end{array}$ \\
\hline $\begin{array}{l}\text { IV Skew*Options } \\
\text { Bid-Ask Spread }\end{array}$ & & & & $\begin{array}{l}66.90 * * \\
(2.20)\end{array}$ & $\begin{array}{l}66.29 * * \\
(2.25)\end{array}$ & $\begin{array}{l}69.51 * * \\
(2.33)\end{array}$ \\
\hline Options Bid-Ask Spread & $\begin{array}{c}0.94 \\
(0.73)\end{array}$ & $\begin{array}{l}-0.18 \\
(-0.13)\end{array}$ & $\begin{array}{l}-0.22 \\
(-0.16)\end{array}$ & $\begin{array}{c}0.39 \\
(0.15)\end{array}$ & $\begin{array}{l}-0.29 \\
(-0.11)\end{array}$ & $\begin{array}{l}-1.33 \\
(-0.49)\end{array}$ \\
\hline Pre-month Return & & $\begin{array}{c}0.58 \\
(0.53)\end{array}$ & $\begin{array}{c}0.52 \\
(0.49)\end{array}$ & & $\begin{array}{c}0.44 \\
(0.33)\end{array}$ & $\begin{array}{c}0.49 \\
(0.37)\end{array}$ \\
\hline Pre-year Return & & $\begin{array}{c}0.01 \\
(0.08)\end{array}$ & $\begin{array}{l}-0.01 \\
(-0.09)\end{array}$ & & $\begin{array}{l}-0.20 \\
(-1.09)\end{array}$ & $\begin{array}{l}-0.20 \\
(-1.02)\end{array}$ \\
\hline Successful & & $\begin{array}{c}0.11 \\
(0.39)\end{array}$ & $\begin{array}{c}0.15 \\
(0.51)\end{array}$ & & $\begin{array}{l}-0.00 \\
(-0.00)\end{array}$ & $\begin{array}{c}0.05 \\
(0.14)\end{array}$ \\
\hline Takeover & & $\begin{array}{l}1.23 * * * \\
(5.12)\end{array}$ & $\begin{array}{l}1.25 * * * \\
(5.16)\end{array}$ & & $\begin{array}{l}1.09 * * * \\
(3.71)\end{array}$ & $\begin{array}{l}1.15 * * * \\
(3.86)\end{array}$ \\
\hline Hostile & & $\begin{array}{l}-1.83^{*} \\
(-1.69)\end{array}$ & $\begin{array}{l}-1.65 \\
(-1.53)\end{array}$ & & $\begin{array}{l}-3.04 * * \\
(-2.16)\end{array}$ & $\begin{array}{l}-3.06 * * \\
(-2.18)\end{array}$ \\
\hline Rumor & & $\begin{array}{l}0.71 * * \\
(2.04)\end{array}$ & $\begin{array}{c}0.63^{*} \\
(1.78)\end{array}$ & & $\begin{array}{c}0.50 \\
(1.28)\end{array}$ & $\begin{array}{c}0.47 \\
(1.17)\end{array}$ \\
\hline Cash & & $\begin{array}{l}0.53^{* *} \\
(2.31)\end{array}$ & $\begin{array}{l}0.51^{* *} \\
(2.17)\end{array}$ & & $\begin{array}{c}0.29 \\
(1.01)\end{array}$ & $\begin{array}{c}0.28 \\
(0.93)\end{array}$ \\
\hline Size & & $\begin{array}{l}-0.26 * * * \\
(-3.32)\end{array}$ & $\begin{array}{l}-0.26 * * * \\
(-3.14)\end{array}$ & & $\begin{array}{l}-0.17 \\
(-1.56)\end{array}$ & $\begin{array}{l}-0.18 \\
(-1.59)\end{array}$ \\
\hline $\mathrm{B} / \mathrm{M}$ & & $\begin{array}{l}-0.20^{*} \\
(-1.65)\end{array}$ & $\begin{array}{l}-0.19 \\
(-1.45)\end{array}$ & & $\begin{array}{l}-0.31^{* *} \\
(-1.98)\end{array}$ & $\begin{array}{l}-0.33^{*} \\
(-1.92)\end{array}$ \\
\hline Year \& Industry control & & & Yes & & & Yes \\
\hline Intercept & $\begin{array}{l}-0.23 \\
(-0.85)\end{array}$ & $\begin{array}{c}1.59 * \\
(1.75)\end{array}$ & $\begin{array}{l}2.43 \\
(0.98)\end{array}$ & $\begin{array}{c}0.24 \\
(0.49)\end{array}$ & $\begin{array}{l}1.29 \\
(0.96)\end{array}$ & $\begin{array}{c}2.40 \\
(0.66)\end{array}$ \\
\hline $\begin{array}{l}N \\
\text { Adj. } R^{2}\end{array}$ & $\begin{array}{r}3,076 \\
0.01\end{array}$ & $\begin{array}{r}3,076 \\
0.02\end{array}$ & $\begin{array}{r}3,076 \\
0.02\end{array}$ & $\begin{array}{r}2,018 \\
0.01\end{array}$ & $\begin{array}{r}2,018 \\
0.02\end{array}$ & $\begin{array}{r}2,018 \\
0.02\end{array}$ \\
\hline
\end{tabular}




\section{Table 8. Cross-Sectional Regressions of Acquirer Announcement Returns on Options to Stock Volume Ratio}

This table shows cross-sectional regressions of absolute value of two-day $(t, t+1)$ acquirer cumulative abnormal return (CAR) around merger and acquisition announcements on day $t-1$ of option to stock volume ratio $(\mathrm{O} / \mathrm{S})$ and control variables. We construct share volume $\mathrm{O} / \mathrm{S}(\mathrm{Sh}$ O/S) according to Roll et al. (2010). Daily share option volume is calculated as the total contracts traded in each option multiplied by 100 (as each contract is for 100 shares of stock) and then aggregated across all options traded on that stock. Sh O/S equals share option volume divided by stock trading volume on that day. Natural logarithm of $\mathrm{Sh} \mathrm{O} / \mathrm{S}$ is used in the following regressions. In regression (3) to (4), $\mathrm{Ln}(\mathrm{Sh} \mathrm{O/S})$ is interacted with absolute CAR for pre-event three days. All other control variables are the same as in Table 4. Both the announcement CAR and the pre-event CAR are expressed in percentage. We compute $t$-statistics (in parentheses) based on White's (1980) heteroskedasticity robust standard errors. ***, **, and * indicate significance at the $1 \%, 5 \%$, and $10 \%$ level, respectively. 


\begin{tabular}{|c|c|c|c|c|}
\hline Model & 1 & 2 & 3 & 4 \\
\hline \multirow[t]{2}{*}{$\operatorname{Ln}(\mathrm{Sh} \mathrm{O} / \mathrm{S})$} & $0.16 * * *$ & $0.15 * * *$ & $0.27 * * *$ & $0.24 * * *$ \\
\hline & $(4.31)$ & $(4.07)$ & $(6.62)$ & $(5.75)$ \\
\hline \multicolumn{3}{|l|}{$\operatorname{Ln}(\mathrm{Sh} \mathrm{O} / \mathrm{S})^{*}$} & $-0.05 * * *$ & $-0.03 * * *$ \\
\hline \multicolumn{3}{|l|}{ Absolute $\mathrm{CAR}_{\mathrm{i},[\mathrm{t}-3, \mathrm{t}-1]}$} & $(-5.89)$ & $(-4.34)$ \\
\hline \multirow[t]{2}{*}{ Pre-month Return } & $-1.50 *$ & $-1.40 *$ & $-1.25^{*}$ & $-1.23 *$ \\
\hline & $(-1.89)$ & $(-1.81)$ & $(-1.65)$ & $(-1.65)$ \\
\hline \multirow[t]{2}{*}{ Pre-year Return } & $0.31 * * *$ & $0.22 *$ & $0.29 * *$ & $0.21 *$ \\
\hline & $(2.61)$ & $(1.91)$ & $(2.49)$ & $(1.87)$ \\
\hline \multirow[t]{2}{*}{ Successful } & 0.01 & 0.04 & 0.04 & 0.06 \\
\hline & $(0.07)$ & $(0.24)$ & $(0.21)$ & $(0.37)$ \\
\hline \multirow[t]{2}{*}{ Takeover } & $-0.84 * * *$ & $-0.82 * * *$ & $-0.84 * * *$ & $-0.83 * * *$ \\
\hline & $(-5.83)$ & $(-5.77)$ & $(-5.96)$ & $(-5.88)$ \\
\hline \multirow[t]{2}{*}{ Hostile } & $1.03 *$ & $1.01 *$ & $1.03 *$ & $1.02 *$ \\
\hline & (1.90) & $(1.81)$ & $(1.90)$ & $(1.85)$ \\
\hline \multirow[t]{2}{*}{ Rumor } & 0.21 & 0.32 & 0.20 & 0.28 \\
\hline & $(0.93)$ & (1.39) & $(0.89)$ & $(1.23)$ \\
\hline \multirow[t]{2}{*}{ Cash } & $-0.39 * * *$ & $-0.27 * *$ & $-0.29 * *$ & $-0.24 *$ \\
\hline & $(-2.88)$ & $(-2.00)$ & $(-2.20)$ & $(-1.77)$ \\
\hline \multirow[t]{2}{*}{ Size } & $-0.77 * * *$ & $-0.76 * * *$ & $-0.68 * * *$ & $-0.69 * * *$ \\
\hline & $(-18.44)$ & $(-17.45)$ & $(-15.98)$ & $(-15.87)$ \\
\hline \multirow[t]{2}{*}{$\mathrm{B} / \mathrm{M}$} & $-0.53 * * *$ & $-0.38 * * *$ & $-0.46 * * *$ & $-0.35 * * *$ \\
\hline & $(-6.81)$ & $(-4.74)$ & $(-5.94)$ & $(-4.43)$ \\
\hline \multirow{3}{*}{$\begin{array}{l}\text { Year \& Industry Control } \\
\text { Intercept }\end{array}$} & & Yes & & Yes \\
\hline & $10.60 * * *$ & $11.07 * * *$ & $9.66 * * *$ & $10.67 * * *$ \\
\hline & $(23.61)$ & $(9.22)$ & (21.39) & $(9.04)$ \\
\hline$N$ & 5,179 & 5,179 & 5,179 & 5,179 \\
\hline Adj. $R^{2}$ & 0.09 & 0.12 & 0.12 & 0.14 \\
\hline
\end{tabular}




\section{Table 9. Robustness Check on Alternative Measures for Implied Volatility Spread and Implied Volatility Skew}

This table shows the regressions of two-day $(t, t+1)$ acquirer cumulative abnormal return (CAR) around merger and acquisition announcements on alternative measures of implied volatility (IV) spread and IV skew. In column (1) and (4), we use deciles of IV spread and IV skew as independent variables. In column (2) and (5), Change in IV spread (or IV skew)_W represents the difference between IV spread (IV skew) on day $t-1$ and the average of previous week (i.e., day $t-6$ to day $t-2$. In column (3) and (6), Change in IV spread (or IV skew)_M represents the difference between IV spread (IV skew) on day $t-1$ and the average of previous month (i.e., day $t-23$ to day $t-2$. All control variables follow the same definitions as in Table 4. CARs are in percentage. We compute $t$-statistics (in parentheses) based on White's (1980) heteroskedasticity robust standard errors. $* * *, * *$, and $*$ indicate significance at the $1 \%, 5 \%$, and $10 \%$ level, respectively. 


\begin{tabular}{|c|c|c|c|c|c|c|}
\hline Model & 1 & 2 & 3 & 4 & 5 & 6 \\
\hline IV Spread Deciles & $\begin{array}{r}0.18^{* * * *} \\
(4.04)\end{array}$ & & & & & \\
\hline Change in IV Spread_W & & $\begin{array}{c}18.67 * * * \\
(4.90)\end{array}$ & & & & \\
\hline Change in IV Spread_M & & & $\begin{array}{c}18.18 * * * \\
(5.35)\end{array}$ & & & \\
\hline IV Skew Deciles & & & & $\begin{array}{l}-0.14 * * \\
(-2.38)\end{array}$ & & \\
\hline Change in IV Skew_W & & & & & $\begin{array}{c}- \\
(-3.17)\end{array}$ & \\
\hline Change in IV Skew_M & & & & & & $\begin{array}{l}- \\
(-3.75)\end{array}$ \\
\hline Pre-month Return & $\begin{array}{c}0.41 \\
(0.38)\end{array}$ & $\begin{array}{c}0.76 \\
(0.72)\end{array}$ & $\begin{array}{c}0.34 \\
(0.32)\end{array}$ & $\begin{array}{c}0.57 \\
(0.44)\end{array}$ & $\begin{array}{c}0.44 \\
(0.32)\end{array}$ & $\begin{array}{c}0.52 \\
(0.39)\end{array}$ \\
\hline Pre-year Return & $\begin{array}{l}-0.01 \\
(-0.06)\end{array}$ & $\begin{array}{l}-0.06 \\
(-0.52)\end{array}$ & $\begin{array}{l}-0.03 \\
(-0.19)\end{array}$ & $\begin{array}{l}-0.20 \\
(-1.03)\end{array}$ & $\begin{array}{l}-0.16 \\
(-0.82)\end{array}$ & $\begin{array}{l}-0.17 \\
(-0.90)\end{array}$ \\
\hline Successful & $\begin{array}{c}0.12 \\
(0.41)\end{array}$ & $\begin{array}{c}0.05 \\
(0.16)\end{array}$ & $\begin{array}{c}0.14 \\
(0.49)\end{array}$ & $\begin{array}{c}0.12 \\
(0.34)\end{array}$ & $\begin{array}{l}-0.04 \\
(-0.11)\end{array}$ & $\begin{array}{c}0.00 \\
(0.01)\end{array}$ \\
\hline Takeover & $\begin{array}{r}1.22 * * * * \\
(5.00)\end{array}$ & $\begin{array}{l}1.16^{* * *} \\
(4.75)\end{array}$ & $\begin{array}{l}1.14 * * * \\
(4.74)\end{array}$ & $\begin{array}{l}1.18^{* * * *} \\
(3.94)\end{array}$ & $\begin{array}{l}1.11^{* * *} \\
(3.71)\end{array}$ & $\begin{array}{l}1.12^{* * * *} \\
(3.72)\end{array}$ \\
\hline Hostile & $\begin{array}{l}-1.65 \\
(-1.52)\end{array}$ & $\begin{array}{l}-1.55 \\
(-1.40)\end{array}$ & $\begin{array}{l}-1.66 \\
(-1.54)\end{array}$ & $\begin{array}{l}-3.18^{* *} \\
(-2.27)\end{array}$ & $\begin{array}{l}-3.16^{* *} \\
(-2.02)\end{array}$ & $\begin{array}{l}-2.97 * * \\
(-2.06)\end{array}$ \\
\hline Rumor & $\begin{array}{c}0.63^{*} \\
(1.79)\end{array}$ & $\begin{array}{c}0.53 \\
(1.51)\end{array}$ & $\begin{array}{c}0.61^{*} \\
(1.75)\end{array}$ & $\begin{array}{c}0.51 \\
(1.26)\end{array}$ & $\begin{array}{c}0.45 \\
(1.11)\end{array}$ & $\begin{array}{c}0.50 \\
(1.26)\end{array}$ \\
\hline Cash & $\begin{array}{c}0.52 * * \\
(2.24)\end{array}$ & $\begin{array}{c}0.46^{*} \\
(1.93)\end{array}$ & $\begin{array}{l}0.47 * * \\
(2.01)\end{array}$ & $\begin{array}{c}0.26 \\
(0.88)\end{array}$ & $\begin{array}{c}0.26 \\
(0.82)\end{array}$ & $\begin{array}{c}0.27 \\
(0.91)\end{array}$ \\
\hline Size & $\begin{array}{l}- \\
(-3.17)\end{array}$ & $\begin{array}{l}-0.18 * * \\
(-2.23)\end{array}$ & $\begin{array}{l}-0.22 * * * \\
(-2.79)\end{array}$ & $\begin{array}{l}-0.20^{*} \\
(-1.80)\end{array}$ & $\begin{array}{l}-0.19 \\
(-1.61)\end{array}$ & $\begin{array}{l}-0.18 \\
(-1.64)\end{array}$ \\
\hline $\mathrm{B} / \mathrm{M}$ & $\begin{array}{l}-0.24 * \\
(-1.83)\end{array}$ & $\begin{array}{l}-0.26^{* *} \\
(-1.97)\end{array}$ & $\begin{array}{l}-0.20 \\
(-1.54)\end{array}$ & $\begin{array}{l}-0.38^{* *} \\
(-2.13)\end{array}$ & $\begin{array}{l}-0.31^{*} \\
(-1.68)\end{array}$ & $\begin{array}{l}-0.30^{*} \\
(-1.71)\end{array}$ \\
\hline Year \& Industry Control & Yes & Yes & Yes & Yes & Yes & Yes \\
\hline Intercept & $\begin{array}{c}0.95 \\
(0.40)\end{array}$ & $\begin{array}{l}1.47 \\
(0.65)\end{array}$ & $\begin{array}{c}1.86 \\
(0.83)\end{array}$ & $\begin{array}{c}2.30 \\
(0.65)\end{array}$ & $\begin{array}{l}1.63 \\
(0.49)\end{array}$ & $\begin{array}{l}1.43 \\
(0.43)\end{array}$ \\
\hline$N$ & 3,076 & 2,937 & 3,052 & 2,018 & 1,891 & 1,974 \\
\hline Adj. $R^{2}$ & 0.02 & 0.02 & 0.03 & 0.01 & 0.01 & 0.02 \\
\hline
\end{tabular}




\section{Table 10. Cross-Sectional Regressions of Target Announcement Return on Implied Volatility Spread and Implied Volatility Skew}

This table presents the cross-sectional regressions of two-day $(t, t+1)$ target cumulative abnormal return (CAR) around merger and acquisition announcements on day $t-1$ of implied volatility (IV) spread and IV skew, with control variables. We rerun all regressions in Table 4, using data for target firms. Panel A contains regressions on IV spread, and Panel B contains regressions on IV skew. CARs are in percentage. We compute $t$-statistics (in parentheses) based on White's (1980) heteroskedasticity robust standard errors. $* * *, * *$, and * indicate significance at the $1 \%, 5 \%$, and $10 \%$ level, respectively. 


\begin{tabular}{|c|c|c|c|c|c|}
\hline \multicolumn{6}{|c|}{ Panel A. IV Spread } \\
\hline Model & 1 & 2 & 3 & 4 & 5 \\
\hline \multirow[t]{2}{*}{ IV Spread } & 11.56 & 9.20 & 1.34 & 3.18 & 1.93 \\
\hline & $(0.98)$ & $(0.81)$ & $(0.13)$ & $(0.33)$ & $(0.20)$ \\
\hline \multirow[t]{2}{*}{ Pre-month Return } & & $-8.37 *$ & $-12.61 * * *$ & $-16.17 * * *$ & $-18.25 * * *$ \\
\hline & & $(-1.93)$ & $(-3.04)$ & $(-4.09)$ & $(-4.48)$ \\
\hline \multirow[t]{2}{*}{ Pre-year Return } & & -0.71 & -0.76 & $-2.43 * * *$ & $-2.31 * * *$ \\
\hline & & $(-0.99)$ & $(-1.17)$ & $(-3.84)$ & $(-3.68)$ \\
\hline \multirow[t]{2}{*}{ Successful } & & & $4.14 * * *$ & $3.74 * * *$ & $3.63 * * *$ \\
\hline & & & (3.12) & $(2.87)$ & $(2.58)$ \\
\hline \multirow[t]{2}{*}{ Takeover } & & & $-18.10 * * *$ & $-16.33 * * *$ & $-15.77 * * *$ \\
\hline & & & $(-3.63)$ & $(-3.77)$ & $(-3.91)$ \\
\hline \multirow[t]{2}{*}{ Hostile } & & & $7.92 * *$ & $10.52 * * *$ & $8.78 * * *$ \\
\hline & & & $(2.57)$ & (3.79) & (3.08) \\
\hline \multirow[t]{2}{*}{ Rumor } & & & $-8.01 * * *$ & $-7.01 * * *$ & $-7.59 * * *$ \\
\hline & & & $(-6.74)$ & $(-5.85)$ & $(-5.81)$ \\
\hline \multirow[t]{2}{*}{ Cash } & & & $10.66 * * *$ & $10.68 * * *$ & $12.07 * * *$ \\
\hline & & & $(7.60)$ & $(7.70)$ & $(7.74)$ \\
\hline \multirow[t]{2}{*}{ Size } & & & & -0.69 & -0.19 \\
\hline & & & & $(-1.61)$ & $(-0.40)$ \\
\hline \multirow[t]{2}{*}{$\mathrm{B} / \mathrm{M}$} & & & & $-4.15^{* * *}$ & $-3.77 * * *$ \\
\hline & & & & $(-4.82)$ & $(-4.51)$ \\
\hline \multicolumn{2}{|l|}{ Year \& Industry Control } & & & & Yes \\
\hline \multirow[t]{2}{*}{ Intercept } & $12.73 * * *$ & $13.71 * * *$ & $9.96 * * *$ & $10.60 * * *$ & 6.81 \\
\hline & (19.64) & $(15.03)$ & $(8.52)$ & $(2.67)$ & $(1.38)$ \\
\hline$N$ & 808 & 805 & 805 & 803 & 803 \\
\hline Adj. $R^{2}$ & 0.00 & 0.01 & 0.20 & 0.23 & 0.24 \\
\hline
\end{tabular}


Table 10 (continued)

\begin{tabular}{|c|c|c|c|c|c|}
\hline \multicolumn{6}{|c|}{ Panel B. IV Skew } \\
\hline Model & 1 & 2 & 3 & 4 & 5 \\
\hline IV Skew & $\begin{array}{c}-19.53 * * \\
(-2.43)\end{array}$ & $\begin{array}{c}-18.27 * * \\
(-2.19)\end{array}$ & $\begin{array}{c}-17.57^{* *} \\
(-2.34)\end{array}$ & $\begin{array}{c}-13.97 * \\
(-1.83)\end{array}$ & $\begin{array}{c}-15.89^{* *} \\
(-2.03)\end{array}$ \\
\hline Pre-month Return & & $\begin{array}{l}-10.65 * * \\
(-2.40)\end{array}$ & $\begin{array}{l}-14.30 * * * \\
(-3.47)\end{array}$ & $\begin{array}{l}-17.78 * * * \\
(-4.36)\end{array}$ & $\begin{array}{l}-19.92 * * * \\
(-4.46)\end{array}$ \\
\hline Pre-year Return & & $\begin{array}{c}-0.17 \\
(-0.31)\end{array}$ & $\begin{array}{c}-0.21 \\
(-0.43)\end{array}$ & $\begin{array}{l}-1.02 * * \\
(-2.04)\end{array}$ & $\begin{array}{l}-1.20 * * \\
(-2.29)\end{array}$ \\
\hline Successful & & & $\begin{array}{l}3.92 * * * \\
(2.76)\end{array}$ & $\begin{array}{l}3.04 * * \\
(2.12)\end{array}$ & $\begin{array}{l}2.61 * \\
(1.74)\end{array}$ \\
\hline Takeover & & & $\begin{array}{c}-12.45 * \\
(-1.66)\end{array}$ & $\begin{array}{l}-11.07 \\
(-1.57)\end{array}$ & $\begin{array}{c}-12.69 * \\
(-1.65)\end{array}$ \\
\hline Hostile & & & $\begin{array}{l}6.37 * \\
(1.70)\end{array}$ & $\begin{array}{l}8.86 * * \\
(2.54)\end{array}$ & $\begin{array}{l}6.46^{*} \\
(1.79)\end{array}$ \\
\hline Rumor & & & $\begin{array}{l}-7.24 * * * \\
(-5.56)\end{array}$ & $\begin{array}{l}-6.32 * * * \\
(-4.73)\end{array}$ & $\begin{array}{l}-6.80 * * * \\
(-4.66)\end{array}$ \\
\hline Cash & & & $\begin{array}{l}9.14 * * * \\
(6.10)\end{array}$ & $\begin{array}{l}9.41 * * * \\
(6.53)\end{array}$ & $\begin{array}{l}10.48 * * * \\
(6.34)\end{array}$ \\
\hline Size & & & & $\begin{array}{l}-0.96 * \\
(-1.87)\end{array}$ & $\begin{array}{l}-0.93 * \\
(-1.76)\end{array}$ \\
\hline $\mathrm{B} / \mathrm{M}$ & & & & $\begin{array}{l}-3.05 * * * \\
(-4.23)\end{array}$ & $\begin{array}{l}-3.13 * * * \\
(-4.43)\end{array}$ \\
\hline Year \& Industry Control & & & & & Yes \\
\hline Intercept & $\begin{array}{l}11.95 * * * \\
(15.42)\end{array}$ & $\begin{array}{l}13.29 * * * \\
(13.44)\end{array}$ & $\begin{array}{l}10.33 * * * \\
(7.85)\end{array}$ & $\begin{array}{l}14.51 * * * \\
(3.12)\end{array}$ & $\begin{array}{l}18.81 * * * \\
(3.63)\end{array}$ \\
\hline $\bar{N}$ & 460 & 459 & 459 & 458 & 458 \\
\hline Adj. $R^{2}$ & 0.01 & 0.02 & 0.24 & 0.27 & 0.31 \\
\hline
\end{tabular}




\section{Appendix Table 1. The Prediction of Option to Stock Volume Ratio on the Occurrence of Merger and Acquisition Event}

This table shows the logit regressions of M\&A event dummy on day $t-1$ option to stock volume ratio $(\mathrm{O} / \mathrm{S})$. and other control variables. $\mathrm{O} / \mathrm{S}$ is defined as in Table 8 . For each acquirer, we select one firm without merger and acquisition (M\&A) announcement on day $t$ as a matching firm, and match on previous fiscal year end size and book-to-market ratio (B/M), past one-year return, as well as industry. M\&A event dummy equals 1 if the firm is an acquirer, and 0 if the firm is a matching firm. All other control variables are the same as in Table 4. $t$-statistics are calculated using White's (1980) heteroskedasticity robust standard errors, and ***, **, and * indicate significance at $1 \%, 5 \%$, and $10 \%$ level respectively.

\begin{tabular}{lcccc}
\hline Model & 1 & 2 & 3 & 4 \\
\hline Ln (Sh O/S) & $0.09^{* * *}$ & $0.08^{* * *}$ & $0.07^{* * *}$ & $0.08^{* * *}$ \\
& $(6.27)$ & $(5.89)$ & $(5.28)$ & $(5.27)$ \\
Pre-month Return & & $0.28^{*}$ & $0.33^{* * *}$ & $0.34^{* *}$ \\
& & $(1.90)$ & $(2.25)$ & $(2.30)$ \\
Pre-year Return & & $0.04^{*}$ & $0.10^{* * *}$ & $0.11^{* * *}$ \\
& & $(1.94)$ & $(3.82)$ & $(3.98)$ \\
Size & & & $0.09 * * *$ & $0.12^{* * *}$ \\
& & & $(6.66)$ & $(7.87)$ \\
B/M & & & $0.15^{* * *}$ & $0.20^{* * *}$ \\
& & & $(4.79)$ & $(5.58)$ \\
Year \& Industry Control & & & & Yes \\
Intercept & $0.63^{* * *}$ & $0.59^{* * *}$ & -0.02 & 0.30 \\
& $(10.88)$ & $(9.89)$ & $(-0.11)$ & $(0.58)$ \\
\hline$N$ & 8,437 & 8,437 & 8,430 & 8,430 \\
Pseudo $R^{2}$ & 0.003 & 0.004 & 0.009 & 0.014 \\
\hline
\end{tabular}




\section{Appendix Table 2. Summary Statistics for Merger and Acquisition Events: Targets}

This table presents summary statistics for targets in merger and acquisition (M\&A) events. Panel A shows the number of events and the number of targets in each year. Panel B shows summary statistics on target firm characteristics. CAR is the cumulative abnormal return from day $t$ to $t+1$ where day $t$ is the announcement date. Option bid-ask spread is the pre-M\&A five-day average bid-ask spread across all options traded on the firm's equity. Analyst coverage equals to the number of IBES analyst recommendations in the month before M\&A. Size is the natural logarithm of market capitalization in millions on the day before M\&A announcement. Age is the number of years that a stock has been covered in CRSP before the M\&A announcement. Idiosyncratic volatility is the standard deviation of the residuals from the Fama-French threefactor model with daily returns in the pre-M\&A 12 months. Std represents standard deviation. Min represents minimum value, and Max represents maximum value. All variables except CAR are winsorized at $1 \%$ and $99 \%$ level. 


\begin{tabular}{|c|c|c|c|c|c|c|c|}
\hline \multicolumn{8}{|c|}{ Panel A. M\&A Events by Year } \\
\hline Year & \multicolumn{4}{|c|}{ Number of M\&A Events } & \multicolumn{3}{|c|}{ Number of Firms } \\
\hline 1996 & \multicolumn{4}{|c|}{113} & \multicolumn{2}{|c|}{106} & \\
\hline 1997 & \multicolumn{4}{|c|}{147} & \multicolumn{2}{|c|}{129} & \\
\hline 1998 & \multicolumn{3}{|c|}{206} & & \multicolumn{2}{|c|}{199} & \\
\hline 1999 & \multicolumn{3}{|c|}{245} & & \multicolumn{2}{|c|}{224} & \\
\hline 2000 & \multicolumn{3}{|c|}{223} & & \multicolumn{2}{|c|}{209} & \\
\hline 2001 & \multicolumn{3}{|c|}{139} & & \multicolumn{2}{|c|}{130} & \\
\hline 2002 & \multicolumn{3}{|c|}{69} & & \multicolumn{2}{|c|}{66} & \\
\hline 2003 & \multicolumn{3}{|c|}{97} & & \multicolumn{2}{|c|}{86} & \\
\hline 2004 & \multicolumn{3}{|c|}{107} & & \multicolumn{2}{|c|}{102} & \\
\hline 2005 & \multicolumn{3}{|c|}{146} & & \multicolumn{2}{|c|}{135} & \\
\hline 2006 & \multicolumn{3}{|c|}{197} & & \multicolumn{2}{|c|}{180} & \\
\hline 2007 & \multicolumn{3}{|c|}{232} & & \multicolumn{2}{|c|}{211} & \\
\hline 2008 & \multicolumn{3}{|c|}{151} & & \multicolumn{2}{|c|}{136} & \\
\hline 2009 & \multicolumn{3}{|c|}{136} & & \multicolumn{2}{|c|}{128} & \\
\hline 2010 & \multicolumn{3}{|c|}{164} & & 149 & & \\
\hline 1996-2010 & & 2,37 & & & 1,990 & & \\
\hline & & nel B: C & racterist & $f \operatorname{targ}$ & & & \\
\hline & Mean & Std & Min & Q1 & Median & Q3 & $\operatorname{Max}$ \\
\hline CAR $(\%)$ & 16.62 & 24.56 & -91.33 & 3.04 & 12.32 & 25.37 & 315.31 \\
\hline Option bid-ask spread & 0.31 & 0.23 & 0.06 & 0.17 & 0.25 & 0.37 & 1.43 \\
\hline Analyst coverage & 9.86 & 6.79 & 1.00 & 5.00 & 8.00 & 13.00 & 33.00 \\
\hline Size & 7.03 & 1.47 & 3.92 & 5.99 & 6.96 & 7.93 & 10.73 \\
\hline Age & 15.65 & 16.22 & 0.83 & 4.28 & 10.33 & 21.40 & 76.61 \\
\hline Idiosyncratic volatility & 0.03 & 0.02 & 0.01 & 0.02 & 0.03 & 0.04 & 0.09 \\
\hline
\end{tabular}




\section{Appendix Table 3. Summary Statistics for Options Measures: Targets}

This table shows summary statistics for the two options measures of target firms, i.e. implied volatility (IV) spread and IV skew. The details for each year are presented in Panel A and B, with the statistics for the whole sample period in the last row of each panel. 


\begin{tabular}{lcccccccc}
\hline \multicolumn{7}{c}{ Panel A. IV Spread Summary Statistics by Year } \\
\hline Year & No. obs. & MEAN & STD & MIN & Q1 & MEDIAN & Q3 & MAX \\
1996 & 45 & 0.0109 & 0.0935 & -0.2690 & -0.0231 & 0.0206 & 0.0701 & 0.1845 \\
1997 & 51 & 0.0360 & 0.1060 & -0.2070 & -0.0250 & 0.0040 & 0.0794 & 0.3987 \\
1998 & 79 & 0.0008 & 0.1154 & -0.6427 & -0.0265 & 0.0022 & 0.0457 & 0.3961 \\
1999 & 96 & 0.0302 & 0.1018 & -0.2058 & -0.0284 & 0.0173 & 0.0890 & 0.3051 \\
2000 & 80 & 0.0167 & 0.0813 & -0.1883 & -0.0212 & 0.0010 & 0.0473 & 0.3960 \\
2001 & 24 & -0.0127 & 0.0840 & -0.2318 & -0.0529 & -0.0030 & 0.0450 & 0.1331 \\
2002 & 12 & -0.0149 & 0.0650 & -0.1254 & -0.0558 & -0.0145 & 0.0132 & 0.1210 \\
2003 & 24 & 0.0006 & 0.0430 & -0.0489 & -0.0227 & -0.0069 & 0.0052 & 0.1497 \\
2004 & 33 & 0.0086 & 0.0290 & -0.0525 & -0.0040 & 0.0022 & 0.0200 & 0.1106 \\
2005 & 48 & -0.0065 & 0.0327 & -0.1016 & -0.0076 & 0.0027 & 0.0091 & 0.0681 \\
2006 & 63 & -0.0047 & 0.0270 & -0.1168 & -0.0147 & -0.0068 & 0.0083 & 0.0752 \\
2007 & 95 & -0.0068 & 0.0293 & -0.1335 & -0.0189 & -0.0035 & 0.0088 & 0.0778 \\
2008 & 44 & -0.0061 & 0.0697 & -0.1996 & -0.0368 & -0.0030 & 0.0192 & 0.1515 \\
2009 & 47 & -0.0099 & 0.0330 & -0.1405 & -0.0211 & -0.0086 & 0.0136 & 0.0494 \\
2010 & 67 & -0.0093 & 0.0519 & -0.2883 & -0.0194 & -0.0070 & 0.0065 & 0.1312 \\
\hline $1996-2010$ & 808 & 0.0047 & 0.0753 & -0.6427 & -0.0215 & -0.0018 & 0.0241 & 0.3987 \\
\hline
\end{tabular}

Panel B. IV Skew Summary Statistics by Year

\begin{tabular}{lcccccccc}
\hline Year & No. obs. & MEAN & STD & MIN & Q1 & MEDIAN & Q3 & MAX \\
1996 & 23 & 0.0043 & 0.0532 & -0.094 & -0.0365 & -0.0001 & 0.0401 & 0.1517 \\
1997 & 25 & 0.0185 & 0.1009 & -0.2571 & -0.0075 & 0.0150 & 0.0778 & 0.1965 \\
1998 & 45 & 0.0182 & 0.0933 & -0.2745 & -0.0161 & 0.0193 & 0.0704 & 0.3042 \\
1999 & 62 & 0.0209 & 0.0930 & -0.1947 & -0.032 & 0.0234 & 0.0793 & 0.2300 \\
2000 & 51 & 0.0390 & 0.1092 & -0.3136 & -0.0019 & 0.0304 & 0.0735 & 0.4952 \\
2001 & 11 & 0.0631 & 0.1038 & -0.0386 & -0.0166 & 0.0340 & 0.1505 & 0.2881 \\
2002 & 3 & 0.0354 & 0.0080 & 0.0263 & 0.0263 & 0.0386 & 0.0412 & 0.0412 \\
2003 & 15 & 0.0495 & 0.0255 & 0.0108 & 0.0291 & 0.0487 & 0.0681 & 0.0976 \\
2004 & 14 & 0.0109 & 0.0591 & -0.1387 & -0.0015 & 0.0289 & 0.0455 & 0.0785 \\
2005 & 24 & 0.0542 & 0.0721 & -0.0348 & 0.0172 & 0.0339 & 0.0679 & 0.2777 \\
2006 & 31 & 0.0434 & 0.0374 & -0.0289 & 0.0173 & 0.0374 & 0.0608 & 0.1657 \\
2007 & 55 & 0.0409 & 0.0573 & -0.0967 & 0.0038 & 0.0315 & 0.0686 & 0.2104 \\
2008 & 27 & 0.0533 & 0.0998 & -0.2163 & 0.0083 & 0.0522 & 0.1260 & 0.2037 \\
2009 & 27 & 0.0572 & 0.0639 & -0.0822 & 0.0206 & 0.0432 & 0.1162 & 0.1699 \\
2010 & 47 & 0.0569 & 0.0484 & 0.0016 & 0.0250 & 0.0423 & 0.0795 & 0.2259 \\
\hline $1996-2010$ & 460 & 0.0368 & 0.0797 & -0.3136 & 0.0032 & 0.0338 & 0.0691 & 0.4952 \\
\hline
\end{tabular}




\section{Appendix Table 4. Target Announcement Returns Sorted by Implied Volatility Spread and Implied Volatility Skew}

This table shows the two-day $(0,+1)$ target cumulative abnormal return $(\mathrm{CAR})$ around merger and acquisition announcements sorted by quintiles of implied volatility (IV) spread and IV skew measured at day $t-1$. For each quintile, we report mean IV spread, mean CAR (in \%) and median CAR (in \%). In parentheses, we show $t$-statistics for mean CAR. For median CAR, we conduct Wilcoxon signed-rank test and show p-value in brackets. The difference between the highest (Quintile 5) and the lowest (Quintile 1) IV spread or IV skew group is also computed in the last column.

\begin{tabular}{|c|c|c|c|c|c|c|}
\hline & 1 (Low) & 2 & 3 & 4 & 5 (High) & High-Low \\
\hline \multicolumn{7}{|c|}{ Sorted by IV Spread } \\
\hline Mean IV Spread & -0.081 & -0.017 & -0.002 & 0.018 & 0.105 & \\
\hline Mean CAR & $\begin{array}{c}11.28 * * * \\
(6.78)\end{array}$ & $\begin{array}{c}11.06 * * * \\
(9.49)\end{array}$ & $\begin{array}{c}13.49 * * * \\
(11.01)\end{array}$ & $\begin{array}{c}12.67 * * * \\
(10.80)\end{array}$ & $\begin{array}{c}15.44 * * * \\
(8.02)\end{array}$ & $\begin{array}{c}4.16 \\
(1.64)\end{array}$ \\
\hline Median CAR & $\begin{array}{c}6.76 * * * \\
{[0.00]}\end{array}$ & $\begin{array}{c}6.02 * * * \\
{[0.00]}\end{array}$ & $\begin{array}{c}10.64 * * * \\
{[0.00]}\end{array}$ & $\begin{array}{c}10.40 * * * \\
{[0.00]}\end{array}$ & $\begin{array}{c}13.12 * * * \\
{[0.00]}\end{array}$ & $\begin{array}{c}6.37 * * \\
{[0.02]}\end{array}$ \\
\hline \multicolumn{7}{|c|}{ Sorted by IV Skew } \\
\hline Mean IV Skew & -0.065 & 0.009 & 0.033 & 0.061 & 0.146 & \\
\hline Mean CAR & $\begin{array}{c}12.39 * * * \\
(8.14)\end{array}$ & $\begin{array}{c}9.89 * * * \\
(7.02)\end{array}$ & $\begin{array}{c}14.92 * * * \\
(8.01)\end{array}$ & $\begin{array}{c}11.60 * * * \\
(7.30)\end{array}$ & $\begin{array}{c}7.35 * * * \\
(5.38)\end{array}$ & $\begin{array}{c}-5.04 * * \\
(-2.47)\end{array}$ \\
\hline Median CAR & $\begin{array}{c}10.55 * * * \\
{[0.00]}\end{array}$ & $\begin{array}{c}7.65 * * * \\
{[0.00]}\end{array}$ & $\begin{array}{c}10.84 * * * \\
{[0.00]}\end{array}$ & $\begin{array}{c}7.31 * * * \\
{[0.00]}\end{array}$ & $\begin{array}{c}3.77 * * * \\
{[0.00]}\end{array}$ & $\begin{array}{c}-6.79 * * * \\
{[0.01]}\end{array}$ \\
\hline
\end{tabular}




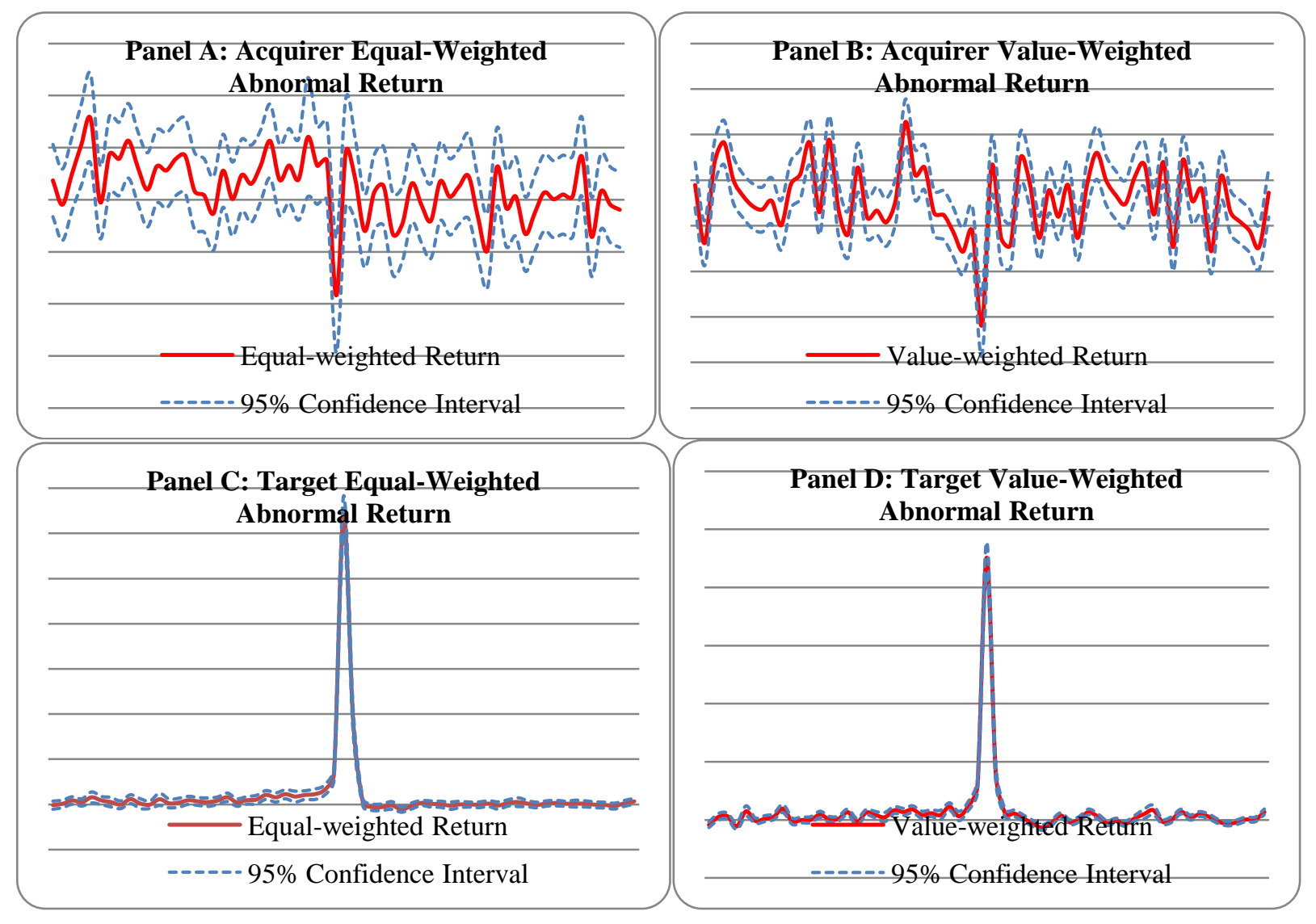

\section{Appendix Figure 1. Average Abnormal Returns Relative to Merger and Acquisition Announcement Dates}

The panels show the daily average abnormal returns for acquirers and targets during day $t-30$ to day $t+30$, where $t$ is the announcement date of merger and acquisition event. Panel $\mathrm{A}$ and $\mathrm{B}$ are for acquirers, and Panel C and D are for targets. Abnormal return is calculated as the daily return subtracted by market value-weighted return. Solid line shows the equal-weighted or valueweighted average returns across all events on each trading day. The $95 \%$ confidence interval is plotted in dashed line. 